\title{
Following Germany's Lead: Using International Monetary Linkages to Estimate the Effect of Monetary Policy on the Economy*
}

\author{
Julian di Giovanni \\ IMF
}

\author{
Justin McCrary $^{\dagger}$ \\ University of Michigan, \\ NBER
}

\author{
Till von Wachter \\ Columbia University
}

\begin{abstract}
April 2006
Abstract

Forward-looking behavior on the part of the monetary authority makes it difficult to estimate the effect of monetary policy interventions on output. We present instrumental variables estimates of the impact of interest rates on quarterly real output for several European countries, using German interest rates as the instrument. These estimates confirm a strong forward-looking bias in least squares estimates that persists even conditional on standard controls for the history of the system. Due to the potential for correlation of output shocks across countries, we interpret our estimates as lower bounds for the effect of monetary policy on real output. Our largest estimates correspond to countries with the weakest economic ties to Germany.
\end{abstract}

${ }^{*}$ We thank participants at the 2004 NBER Summer Workshop in Monetary Economics and the Federal Reserve Bank of Chicago for helpful comments. Any errors are our own. This paper should not be reported as representing the views of the IMF. The views expressed are those of the authors and do not necessarily reflect the views of the IMF or IMF policy.

$\dagger$ Address: University of Michigan, 440 Lorch Hall, Ann Arbor, MI 48109. E-mail: jmccrary@umich.edu. 


\section{Introduction}

A recurring question in economics is the extent to which monetary policy interventions affect the real economy. Assessing the magnitude of these effects empirically is inherently difficult due to central bank efforts at anticipating trends in growth and inflation. As discussed in the literature, this forward-looking aspect of monetary policy imparts a downward bias on the estimates of the real impact of interventions. ${ }^{1}$

One solution to this problem is to isolate sources of variation in monetary policy that are not themselves correlated with the economic outcomes of interest. Although such variation is rare in a macroeconomic setting, institutional arrangements may occasionally constrain a central bank's behavior and lead to deviations from systematic forward-looking monetary policy. Thus, these institutional features can sometimes lead to recurring 'natural' experiments in monetary policy. This type of approach is discussed in a recent paper by Tenreyro and Barro (2003), who argue that currency arrangements such as dollarization can be used as an instrument for the effect of the exchange rate regime on bilateral outcomes between dollarizing countries.

In this paper, we present instrumental variables (IV) estimates of the effect of monetary policy on real output for several European countries in the pre-EMU period, using German interest rates as the instrument. We thereby exploit quasi-experimental variation in interest rates generated by the adherence of smaller countries to the interest rates of an "anchor" country within a system of fixed exchange rates. ${ }^{2}$ The economic and institutional environ-

\footnotetext{
${ }^{1}$ The empirical literature on the effect of monetary policy on the economy is vast; see Christiano, Eichenbaum and Evans (1999). Isolating exogenous variation in monetary policy to estimate its effect has been a major theme in the literature. Andersen and Jordon (1968) is an early paper showing how policy endogeneity can affect estimates of the impact of monetary policy on the economy in the context of a "St. Louis Equation". A recent paper by Romer and Romer (2004) follows in the tradition of Friedman and Schwartz (1963), seeking to identify periods of exogenous shifts in monetary policy. A large number of papers use the VAR approach developed by Sims $(1972,1980 \mathrm{a}, 1980 \mathrm{~b})$ to estimate the effect of monetary policy. For recent summaries, see, for example, Watson (1994) and Stock and Watson (2001).

${ }^{2}$ Many European countries followed Germany's lead in setting their monetary policy during our sample period, 1973-1998, making Germany effectively the anchor country (von Hagen and Fratianni 1990). Theoretical arguments in favor of fixed exchange rates in Europe are reviewed by Giavazzi and Giovan-
} 
ment in Europe during the time frame of our study allows us to give our IV estimator a clear economic interpretation. We develop a simple framework that allows us to explicitly address several threats to interpretation, in particular the role of common output shocks.

Our primary findings are as follows. First, as other people have found (e.g., Clarida, Galí and Gertler 1998), we document a strong and precisely estimated correlation of home interest rates with German interest rates. This relationship is sufficiently strong that the important statistical concerns with 'weak instruments' are not at issue here (Stock, Wright and Yogo 2002). Second, IV estimates confirm powerful real effects of monetary policy. Our estimates suggest that a 5 percentage point increase in interest rates leads to a recessionary contraction in annual real growth of 2 to 3 percentage points. Third, IV estimates are decisively more negative than OLS - typically 3 to 4 times as large in magnitude - suggesting a strong forward-looking component of European monetary policy in the pre-EMU period. Fourth, the magnitude of the OLS-IV difference is not diminished by the inclusion of standard controls of the recent history of the system. We interpret this as suggestive evidence that, for the European countries we study, controlling for the recent history of the system does not adequately capture central bankers' information set. This underscores the potential relevance of recent extensions of the VAR approach to control variables of extremely high dimension (Bernanke and Boivin 2004, Bernanke, Boivin and Eliasz 2005, Stock and Watson $2005) .^{3}$

If output shocks are correlated across countries, then our IV approach will not fully eliminate the endogenous component of monetary policy. We argue that this leads our estimates to be overly conservative. Specifically, we show that under mild assumptions the

nini (1989), among others, and go back to arguments made in the context of the Mundell-Fleming model (Mundell 1963, Fleming 1962), and the original work on optimal currency areas of Mundell (1961). Within the European context, several authors stressed the benefits of avoiding the problem of time inconsistency building on work by Kydland and Prescott (1977) and Barro and Gordon (1983). An elegant recent survey and treatment of the subject is found in Alesina and Barro (2002) within the context of currency unions.

${ }^{3}$ See also Boivin and $\mathrm{Ng}(2003)$. 
probability limit of the IV estimate is a convex combination of the true parameter and the probability limit of the OLS estimate, with the degree of output correlation as the weighting factor. If output shocks were uncorrelated, IV would estimate the true effect of monetary policy. More plausibly, if output shocks were positively correlated, IV would understate the true consequences of monetary policy interventions, but would be expected to outperform OLS. Since our IV estimates are markedly and significantly more negative than OLS, it follows that if our estimates are biased, we are understating the real consequences of monetary policy interventions. This leads us to view our estimates as lower bounds for the true real effects of monetary policy. In fact, our estimates are somewhat more modest than those of, for example, Romer and Romer (2004), consistent with the proposition that there is a remaining bias in our main IV estimates.

To further investigate the potential for remaining bias in our IV estimates, we correlate our estimates with underlying macroeconomic determinants, such as the fraction of home country gross domestic product arising from trade with Germany or the degree of remaining monetary policy independence. Consistent with the literature on monetary policy interdependence and optimum currency areas, our results suggest that the bias is particularly important for larger European countries with a higher degree of monetary policy independence. $^{4}$

Our results are also relevant for several literatures not directly concerned with estimating the real effects of monetary policy interventions. First, our empirical results show the effect of an anchor country's interest rate movements on economic outcomes in countries pegging their exchange rate to that of the anchor country. Recent papers have discussed the extent to which international monetary linkages may limit a country's ability to conduct independent monetary policy (Shambaugh 2004, Obstfeld, Shambaugh and Taylor 2005, Obstfeld,

\footnotetext{
${ }^{4}$ See the previous footnote. Furthermore, our results line are in line with those of Bayoumi and Eichengreen (1993) who find that commonality of shocks is greatest between Germany and its "core" surrounding countries (France, Belgium, the Netherlands, and Austria).
} 
Shambaugh and Taylor 2004). Second, our first-stage estimates are closely related to recent estimates of the reaction functions of European central banks in Clarida and Gertler (1997) and Clarida, Galí and Gertler (1998). ${ }^{5}$ Third, our results also relate to an extensive literature examining the cost and benefits of fixed exchange rates, particularly in reference to the EMS and EMU. ${ }^{6}$

The remainder of the paper is organized as follows. Section II describes the identification strategy and describes how our approach may be understood as a structural VAR with prior restrictions on the dynamic effects of interest rates on output. In that section, we also describe the dynamic interpretation of our estimate, which is the economic consequences of an episode of tightening. The main empirical results of the paper are presented in Section III, and Section IV concludes.

\section{Identification strategy}

If central banks choose monetary policy taking into account information about future output growth, simple OLS estimates of the effect of interest rates on output growth are likely to be biased. However, central banks may pursue policy goals that are not directly related to output innovations. For example, countries often peg their currency to that of an anchor country to obtain credibility, stabilize financial markets, or reduce inflation. Some central banks even choose anchors for their monetary policy in order to detach interventions from output stabilization. Alternative goals can provide additional estimation strategies that allow consistent estimation of at least partial effects of monetary policy on the real economy.

Suppose the central bank sets monetary policy taking into account expected future in-

\footnotetext{
${ }^{5}$ Taylor (1993) discusses the concept of an interest rate policy rule. See Woodford (2003) for a comprehensive analysis of optimal interest rules. An early theoretical and empirical assessment of interest rate targeting goes back to Barro (1988).

${ }^{6}$ This literature is summarized by Eichengreen (1990) and Wyplosz (1997), among others.
} 
flation and output growth according to the reaction function

$$
i_{t}=\beta_{0}+\beta_{1} \hat{y}_{t \mid t-1}+\beta_{2} \hat{\pi}_{t+1 \mid t-1}+v_{t},
$$

where the interest rate $\left(i_{t}\right)$ is taken to be the central bank's main policy tool, $\hat{y}_{t \mid t-1}=$ $E\left[y_{t} \mid \Omega_{t-1}\right]$ and $\hat{\pi}_{t+1 \mid t-1}=E\left[\pi_{t+1} \mid \Omega_{t-1}\right]$ denote the monetary authority's forecast of real output growth and the lead of inflation based on information available as of date $t-1$ and assuming no change in stance, and $v_{t}$ is an orthogonal policy disturbance. Such a reaction function has been proposed by Clarida, Galí and Gertler (2000) based on Taylor (1993), but a forward-looking component of monetary policy is implicit in many classic discussions of monetary policy (e.g., Bernanke and Blinder 1992, Bernanke and Mihov 1998, or Romer and Romer 1989). ${ }^{7}$

A common regression specification in the literature for a linear relationship between real output growth $\left(y_{t}\right)$ and the interest rate $\left(i_{t}\right)$ has been

$$
y_{t}=\alpha_{0}+\theta i_{t}+\phi_{1}^{\prime} W_{t-1}+u_{t}
$$

where $\theta$ represents the short run causal effect of interest rates on the real economy, and $W_{t-1}$ may include other variables such as inflation as well as lags of variables in the system. The ordinary least squares estimator of $\theta$ will be consistent if conditional on $W_{t-1}$ the interest rate $i_{t}$ is uncorrelated to the error component, i.e., if

$$
C\left[u_{t}, i_{t} \mid W_{t-1}\right]=0
$$

Given the central bank's reaction function (1), it is clear this will only be the case if the variables at the researcher's disposal are sufficient for the central bank's information set. However, generally $W_{t-1}$ is likely to be a strict subset of $\Omega_{t-1} \cdot{ }^{8}$ Even in the unusual case

\footnotetext{
${ }^{7}$ Equation (1) has also become integral part of recent theoretical models of monetary policy and the open economy such as Benigno (2004), Engel and West (2004), or Galí and Monacelli (2005).

${ }^{8}$ Another requirement for consistency is that the lag-structure of the model be specified correctly, see below.
} 
when the econometrician observes the actual forecasts of output growth and inflation used by the monetary authority, as in Romer and Romer (2004), it is probably true that monetary policymakers on occasion downplay forecasts that seem out of line with conventional wisdom regarding the health of the economy or the future path of inflation, and esteem forecasts that confirm such views. ${ }^{9}$

An IV approach in this context seeks to control directly the source of movements in the interest rate. Suppose for example that the central bank has goals that are uncorrelated with short run swings of the national economy. Such goals can provide an observable source of shocks to the interest rate that allow consistent estimation of the causal short run effect of monetary policy on output growth $\theta$. The basic idea behind this approach goes back to Friedman and Schwartz (1963) and Romer and Romer (1989) who sought to identify the effect of monetary policy on the real economy by finding situations in which the change in the stance of monetary policy was not only dictated by immediate economic circumstances.

Concretely, consider the following alternative specification of reaction functions for European central banks in the 1980s and 1990s,

$$
i_{t}=\beta_{0}+\beta_{1} \hat{y}_{t \mid t-1}+\beta_{2} \hat{\pi}_{t+1 \mid t-1}+\beta_{3} z_{t}+\nu_{t}
$$

where $z_{t}$ could be an exchange rate target or a foreign interest rate. If this additional target is uncorrelated with central banks' expectation of future output or inflation realizations, then it leads to changes in the interest rate that are uncorrelated with the disturbance in Equation (2). Instead of (3) the orthogonality condition becomes $C\left[u_{t}, z_{t} \mid W_{t-1}\right]=0$, which is the generic condition for the validity of an IV estimator. The system of equations corresponding to the IV estimate consists of Equation (2) and an equation for the interest rate. Using the policy reaction function (4), the first-stage regression can be written as

$$
i_{t}=\beta_{0}+\phi_{2}^{\prime} W_{t-1}+\beta_{3} z_{t}+\eta_{t},
$$

\footnotetext{
${ }^{9} \mathrm{An}$ econometric interpretation of this phenomenon is that the coefficients on the forecasts in Equation (1) are time-varying, whereas the econometrician estimates time-constant coefficients.
} 
where the error $\eta_{t}$ is the sum of $\nu_{t}$ and an error reflecting the differences in the information of the researcher and the central bank. If $z_{t}$ is uncorrelated with $u_{t}$, the error in Equation (2), then $z_{t}$ generates quasi-experimental variation in $i_{t}$ that allows for consistent estimation of the causal short run effect of nominal interest rates on the economy.

The identification strategy we pursue may be understood as a highly parsimonious structural VAR with a focus on identification of a single parameter. Suppressing intercepts, a VAR comparable to the two-equation system used here can be written as

$$
\left(\begin{array}{cc}
1 & -\theta \\
0 & 1
\end{array}\right)\left(\begin{array}{c}
y_{t} \\
i_{t}
\end{array}\right)=\left(\begin{array}{l}
\phi_{1} \\
\phi_{2}
\end{array}\right) W_{t-1}+\left(\begin{array}{c}
\epsilon_{1 t} \\
\epsilon_{2 t}
\end{array}\right)
$$

Identification within this system of equations is usually specified in terms of the matrix on the contemporaneous correlations alone, leaving the structure of lags completely flexible. ${ }^{10}$ A common identifying assumption is to exclude contemporaneous feedback of output growth on the interest rate (or of interest rates on output, which is equivalent in statistical terms), setting to zero the lower left hand parameter of the matrix of contemporaneous correlations. This identification strategy is equivalent to imposing assumption (3) conditional on all of the lags of the system. ${ }^{11}$

Augmenting the above system by an equation for the German interest rate and freeing up the zero restriction yields

$$
\left(\begin{array}{ccc}
1 & -\theta & 0 \\
\lambda & 1 & \beta \\
0 & 0 & 1
\end{array}\right)\left(\begin{array}{c}
y_{t} \\
i_{t} \\
z_{t}
\end{array}\right)=\left(\begin{array}{l}
\phi_{1} \\
\phi_{2} \\
\phi_{3}
\end{array}\right) W_{t-1}+\left(\begin{array}{c}
\epsilon_{1 t} \\
\epsilon_{2 t} \\
\epsilon_{3 t}
\end{array}\right) .
$$

where now identification of $\theta$ can rely on the zero restriction in the upper right corner of the matrix of contemporaneous correlations. In this system of equations the restriction $\lambda=0$ is

\footnotetext{
${ }^{10}$ In the earlier literature on VARs, identification of the effects was mainly based on the ordering of variables and a factorization of the error matrix to achieve a recursive system. In the case of structural VARs, restrictions on the matrix of contemporaneous correlations are determined by economic theories; the resulting system can but need not be recursive; see e.g., Bernanke (1986) or Blanchard and Watson (1986).

${ }^{11}$ In standard VAR analysis, this assumption means that the reduced form of the system may be estimated consistently by least squares. The structural disturbances are then obtained from the reduced form residuals by method-of-moments techniques. These in conjunction with the parameter estimates of the lag-structure are then used for further analysis.
} 
not needed for identification. ${ }^{12}$

In our empirical application, we argue that the German central bank was the leader for monetary policy for many European countries indirectly since the break down of Bretton Woods, and directly since the conception of the European Monetary System (EMS) in 1979. As noted above, estimates of the degree of leadership differ in the literature (e.g., Giavazzi and Giovannini 1987, or von Hagen and Fratianni 1990); this is a substantively important point, but does not compromise our methodology. Clarida et al. (1998) and Clarida and Gertler (1997) describe how the Bundesbank's reaction function is similar to that of the Federal Reserve, and can be well described by Equation (1). They find a statistically significant but economically small role for the US-DM exchange rate. On the other hand, Clarida et al. (1998) show that the German interest rate plays an important role in the reaction function of France, Italy, and the UK. ${ }^{13}$ Based on these considerations, we use the German interest rate as an instrument for the nominal rate of other European countries and provide explicit estimates of relationship (5). That countries constrain the scope of their domestic monetary policy also receives empirical support from recent work by Shambaugh (2004) and Obstfeld, Shambaugh and Taylor $(2005, \mathrm{~b})$ who show that the co-movement of interest rate changes is higher under pegged exchange rates than under floating rates. ${ }^{14}$

Since European economies are closely linked by trade flows and financial markets, output and inflation innovations are likely to be correlated across countries (Frankel and Rose 1998). This will lead IV estimates to have a remaining bias. In our empirical application, we will include lags of domestic output growth and inflation to absorb sources of co-movement in

\footnotetext{
${ }^{12}$ Hamilton (1994) gives a discussion of a system such as that represented above.

${ }^{13}$ The authors do not analyze the role of European exchange rates in the Bundesbank's reaction function, nor do they explicitly compare the role of exchange rates vs. interest rates in the other countries' functions.

${ }^{14}$ Their approach is similar to ours in that they also try to estimate the correlation between countries' interest rates to that of an anchor country. Invoking uncovered interest rate parity, these authors argue that estimating interest relationships in levels is inappropriate if interest rates of the anchor country are highly persistent. This is less likely to be a problem in our application, since for part of the period capital controls were in place and the time horizon we consider is relatively short. Additionally, we argue below that our approach may be understood as uncovering a co-integrated relationship.
} 
interest rates due to economic factors. However, it is likely that in a macroeconomic context it will be hard to absorb all sources of correlation across countries. We next discuss a framework for the likely bias of the IV estimator. To preview the conclusion of the discussion, we will argue that our IV estimates - which are substantially larger in magnitude than OLS - are arguably too conservative under the plausible assumption that output shocks are correlated across Europe.

Suppose that $\delta$ is the coefficient on German output growth innovations in the population regression of home country output growth innovations on German innovations (loosely, the correlation of output shocks). Then asymptotically, the IV estimator is a convex combination of the target parameter and OLS:

$$
\hat{\theta}_{I V} \stackrel{p}{=}(1-\alpha) \theta+\alpha \hat{\theta}_{O L S}
$$

where the weighting factor $\alpha$ is

$$
\alpha=\frac{B_{O L S}^{*}}{B_{O L S}} \times \frac{\delta}{\beta_{3}}
$$

where $B_{O L S}^{*}$ and $B_{O L S}$ denote the bias of OLS estimates for Germany and the home country, respectively (e.g., $B_{O L S} \equiv \operatorname{plim} \hat{\theta}_{O L S}-\theta$ ), and $\beta_{3}$ is the coefficient on the German interest rate in the first-stage Equation (5). ${ }^{15}$ Thus, the more correlated German and domestic output shocks, the more is IV biased towards OLS. However, even with a moderately positive output shock correlation, a strong interest rate correlation can lead IV to dominate OLS. Quantitatively comparing the bias of IV to the bias of OLS is not difficult. The calculations become somewhat tedious, because under Equation (5), as the interest rate correlation grows, OLS becomes less biased since the variance of home country interest rates is increasingly dominated by the variance of German interest rates. To avoid tedium, details on the exact calculations are given in Appendix A. There, it is shown that, given the strength of the first-

\footnotetext{
${ }^{15}$ We use the notation $A \stackrel{p}{=} B$ when $A$ and $B$ share a probability limit, and we refer to the discrepancy between an estimator's probability limit and its target as its bias.
} 
stage relationship documented below, IV will be less biased than OLS unless the correlation of output shocks exceeds 0.95 , which we deem implausibly high.

We can use Equation (6) to relate the relative bias to countries' macroeconomic relationships with Germany. For example, if a country is heavily dependent on trade with Germany (relative to its GDP), then shocks that hit Germany will be directly transmitted to the domestic economy as German supply and demand for goods adjust. In this case, forward looking monetary choices by the Bundesbank will be correlated with a country's GDP growth, making it more difficult to differentiate between the OLS and IV estimates. ${ }^{16}$ Factors governing the degree of a country's monetary independence also determine the relative bias between IV and OLS. For example, the wider exchange rate bands in target zone, the more can domestic interest rates temporarily deviate from those of the anchor country. If larger "effective" exchange rate bands imply higher exchange rate volatility, we expect the size of the OLS-IV difference (IV estimate) to be positively related to volatility.

A practical issue that we have to address in the case of open economies is that real exchange rate changes may lead to both an increase in interest rates as well as improvement in competitiveness. For example, if the Bundesbank lowers interest rates in response to a worsening of the German terms of trade (which it is known to have done, see Clarida and Gertler 1997) and if the French terms of trade were simultaneously improving, then our instrument may itself suffer from omitted variable bias. We have therefore tried to include lags of the real exchange rates as additional controls in our models. The results were basically unchanged. ${ }^{17}$

A possible drawback of our approach is that $\theta$ is a measure of the short run causal effect of a change in interest rates on economic growth. Typically, $W_{t-1}$ contains several lags of the

\footnotetext{
${ }^{16}$ Another measure of similarity between countries is bilateral distance. Thus, one would expect that the size of the IV estimator and of the OLS-IV difference to be increasing with distance.

${ }^{17}$ Note that we do not want to control for the transmission of interest rate changes through the real exchange rate. Similarly, the current real exchange rate might be an outcome variable in itself. Therefore we do not include the contemporaneous real exchange rate as a control variable.
} 
interest rate, and researchers have been interested in the entire dynamic path of the effect of interest rate shocks. In Appendix B we show that in an environment where monetary policy affects the economy with a lag, estimation of a static model such as ours combines the current effect of monetary policy with a weighted sum of the effects of past policy. ${ }^{18}$ The intuition for this result is straightforward and is based on the omitted variable bias formula. Essentially, our estimates of the effect of interest rates on output will reflect not just the effect of the current period's interest rate, but additionally the effect of past interest rates, since these are correlated with current period interest rates. Our estimates represent, then, not the effect of a one-period interest rate increase, but the reduced form effect of an episode of interest rate increases.

A shortcoming of this reduced form parameter is that the boundaries of the episode in question are determined not by the economist, but by the data. For example, if high interest rates in the current quarter signal that interest rates were high for the past 3 quarters, then the reduced form parameter will represent the effects of a year's worth of tightening. However, this reduced form parameter is of economic interest; it measures the effect of an episode of contractionary monetary policy, where an episode is defined on the basis of the historical tendencies of the monetary authority.

If we treat the lag of interest rates as predetermined, a simple dynamic extension of our IV approach would amount to using $z_{t-1}$ as an additional instrument for $i_{t}$. An alternative would be to treat both $i_{t}$ and $i_{t-1}$ as endogenous and to instrument them by $z_{t}$ and $z_{t-1}$. However, interest rates tend to be highly persistent. While this is also a problem for identification in standard vector autoregression models that include multiple lags of the interest rate, it is a particular problem for IV estimation-while statistical issues with weak instruments are not an issue for identifying the reduced form parameter we estimate estimate here, they

\footnotetext{
${ }^{18}$ As the more detailed presentation in Appendix B makes clear, our estimates may be viewed as a functional of the impulse response function, where the functional is chosen adaptively by the data.
} 
are arguably the key problem for a dynamic extension of our approach. Essentially, current and lagged foreign interest rates do not provide enough distinct variation to function as two separate instruments. Thus, in the empirical section we limit ourselves to discussing some estimates for the case in which $i_{t-1}$ is treated as predetermined in the sensitivity analysis.

\section{Data and empirical results}

\section{A. Data and empirical implementation}

We estimate OLS and IV regressions of the impact of nominal short term interest rates on real output growth for eleven European countries using quarterly data from 1973 to 1998. These countries are chosen given data availability and include but are not limited to most participants in the European Monetary System (EMS): The countries are Austria, Belgium, France, Great Britain, France, Italy, Netherlands, Norway, Portugal, Spain, Sweden, and Switzerland. ${ }^{19}$ Nominal GDP data are taken from the International Monetary Fund's International Financial Statistics (IFS) database and are deflated by each country's real GDP deflator $(1995=100$, also from the IFS database). To control for seasonal components we include quarterly dummies in all specifications. We lack complete data for quarterly GDP for Belgium, Italy, the Netherlands, Portugal, and Sweden in the 1970s. ${ }^{20}$ The short-term interest rate by which we measure monetary policy is the overnight lending or call money rate from the Global Financial Database. We average end-of-month rates quarterly. ${ }^{21}$ We also have tried using the central bank's discount rate, and the three month T-bill rate (annualized). Our results are generally robust to the choice of interest rates used.

The main estimation equations are (2) and (5), where the level of the quarterly German

\footnotetext{
${ }^{19}$ Notable exceptions due to data limitations on quarterly nominal interest rates are Denmark and Ireland.

${ }^{20}$ Data are missing from 1973Q1-1980Q2 (Belgium), 1973Q1-1977Q1 (Netherlands), 1973Q1-1977Q1 (Portugal), and 1973Q1-1980Q1 (Sweden). For Portugal we are also missing interest rate data from 1973Q11975Q3.

${ }^{21}$ Overnight/call money rates are missing for two countries: 1973Q1-1978Q2 (Italy) and 1973Q1-1975Q3 (Portugal).
} 
overnight rate is used as an instrument for the level of the call money rate in the other European countries. It is widely accepted in the literature that the German central bank became the effective trend-setter in the stance of monetary policy for other European countries since the break down of the Bretton-Woods system. This role of leadership was strengthened within the EMS founded in $1979,{ }^{22}$ and a large literature grew out of the attempt to quantify and explain the degree of the ensuing asymmetry. ${ }^{23}$ Some have argued that Germany effectively ran monetary policy for the entire EMS (e.g., Giavazzi and Giovannini 1987); others have argued that German dominance left room for own monetary policy action as intended by the founders of the EMS (e.g., von Hagen and Fratianni 1990). Thus, while German monetary policy seems to have been a strong influence on countries' interest rates, this did not negate forward-looking behavior on the part of the monetary policy, particularly for larger countries within the EMS, and those who joined late or had wider exchange rate bands. For the smaller, open countries on the other hand, pegged exchange rates and flexible capital markets may have left little scope for independent monetary policy. ${ }^{24}$ This may have made a difference for countries whose output shocks correlated closely with those of Germany. After presenting the basic results we will address these predictions directly.

\footnotetext{
${ }^{22}$ This system was precluded by an informal joint float against the dollar known as the "snake". Members of this system were Belgium, Germany, Luxembourg, and the Netherlands. France, Great Britain and Italy participated briefly and sporadically in the snake during the 1970s.

${ }^{23}$ The original members of the EMS (and their initial exchange rate bands) in 1979Q1 were Belgium $( \pm 2.25 \%$, Denmark $( \pm 2.25 \%)$, France $( \pm 2.25 \%)$, Germany $( \pm 2.25 \%)$, Ireland $( \pm 2.25 \%)$, Italy $( \pm 6 \%)$, Luxembourg (1979Q2, $\pm 2.25 \%)$, the Netherlands $( \pm 2.25 \%)$. Late joiners included Great Britain $(1990 \mathrm{Q} 1, \pm 6 \%)$, Portugal (1992Q1, $\pm 6 \%$ ), and Spain (1990Q1, $\pm 6 \%$ ). Note that the exchange rate band expanded, for all countries remaining in the EMS, to $\pm 15 \%$ in 1993Q3. See Table A3 for more details on the realignments over time.

${ }^{24}$ The existence of flexible capital markets was not always the case during the EMS-period. As Giavazzi and Giovannini (1989) point out, the use of capital controls were predominant in many of the "weaker" currency countries. Paradoxically, Giavazzi and Giovannini find that though these controls had a tendency to break the link between interest rates (as measured by the differential in movements of on-shore and offshore rates), they could not reject France and Italy's monetary policy from being different from Germany's during the period.
} 


\section{B. Main Empirical results}

We first present results for a simple baseline model with no additional covariates included. Table 1 contains results for a regression of real quarterly output growth on nominal interest rates for all countries, sorted by GDP. The baseline specification is only correct under the stylized case in which the central bank controls the interest rate directly, and has as its only objective the smoothing of output. In this special case, the interest rate is only a function of the central bank's projection of shocks that are unexpected by the market (thus, interest rates should be orthogonal to any market information). Clearly, the interest rate is in effect also determined by market forces as well as by other policy goals of the central bank. For example, if the central bank uses the interest rate to manage inflation, and lagged inflation correlates positively with output growth, then the coefficient on nominal interest rates in a growth regression might understate the effects of monetary policy. Additional covariates also help to partially control for forward-looking behavior of the central bank and thereby reduce the potential bias of OLS estimates. Therefore, Table 1 also adds four lags of real output growth and inflation to our baseline specification. (Table 2 and 3 present further regression specifications for models that pools multiple countries.) All tables report two sets of standard errors; usual heteroscedasticity robust Eicker-White standard errors are in parentheses, and Newey-West standard errors correcting for 4th order serial correlation are in squared brackets. The two sets of standard errors are quite similar, and the choice of standard error affects our results only for very few cases. Neither seems to be overall more conservative, so we chose to report both.

Basic OLS estimates of the effect of monetary policy are shown in Column (1) of Table 1. Taken at face value, these estimates imply that a one percentage point increase in the interest rate lowers quarterly real growth only moderately: 0.094 percentage points in the Netherlands and only 0.015 percentage points in France. The average effect across countries is -.043 , the median is -.039. To summarize the basic relationship across countries, and help 
to assess the impact of different specifications on the overall effect of monetary policy, we also pool our results using several alternative variables as weights. The pooled OLS estimates are shown in Table 2. Specifically, pooled estimates are presented in which countries are equally weighted [Pooled 1] and weighted by (i) GDP in 2003 US Dollars [Pooled 2], (ii) the fraction of their GDP not due to trade [Pooled 3], and (iii) the volatility of their exchange rate vis-a-vis the German Mark [Pooled 4]. ${ }^{25}$ The pooled estimates also help to assess to what extent our results are common across countries or driven by outliers. We do not view them as an estimate of a common underlying parameter, but rather as a summary measure of the individual coefficients. ${ }^{26}$ However, in calculating the pooled estimates, we restrict the first stage and reduced form coefficients to be equal across countries for computational reasons. ${ }^{27}$ The average effect for the pooled OLS results without control variables in Row (A) of Table 2 is -0.031 percentage points, where the equally weighted [Pooled 1] yields the most negative OLS estimates with -.0325.

The corresponding estimates using the German interest rate as an instrument for the national interest rate are shown in Column (3) of Table 1. For all countries (except Austria and Belgium), the IV estimates are more negative than the OLS estimates. This suggests that some degree of endogeneity with respect to real output growth affects most countries' interest rates. A simple interpretation of this endogeneity is that it is capturing the extent to which the monetary authority is forward-looking. The pooled IV estimates in Row (A) of Table 3 summarize this result: the IV estimate suggests that a one percentage point increase

\footnotetext{
${ }^{25}$ See Appendix Table A1 for the weights used for these regressions as well as other summary statistics.

${ }^{26}$ In the case of fixed country-specific weights, one can show that the pooled estimates are a weighted function of the country-specific coefficients (with weights proportional to the fixed country-weight in the pooled model).

${ }^{27}$ It would seem sensible to allow country-specific first-stage coefficients to reflect differences in the underlying mechanism across countries. However, doing so we face a problem of multiple weak instruments very similar to that faced by Angrist and Krueger (1991), who also interact their instrument with state-dummies. As discussed in the ensuing literature on weak instrument, this risks 'over-fitting' the first-stage relationship and biases IV results towards OLS. However, our pooled estimates are remarkably similar to the sum of the separate estimates weighted by the inverse of their variances (the optimal method-of-moments estimator under the hypothesis of a common coefficient), suggesting to us that this limitation may not be severe.
} 
in interest rates (on average) causes a reduction in real output growth of 0.113 percentage points, which exceeds the OLS estimate by a factor of three. Column (2) also shows the only case for which choice of standard errors makes a sizeable difference for significance levels Spain. The differences between OLS and IV is always statistically significant in the pooled models. For single countries, the difference between OLS and IV is shown in Columns (3) and (6) of Table 1. It is generally significant and larger for bigger countries (e.g., Great Britain, France, Italy, and Spain), as expected and further discussed below. ${ }^{28}$

To the extent that the central bank pursues other policies or is forward-looking, the results of the baseline model without other regressors might be affected by a bias from confounders affecting both nominal interest rates and real output growth. As discussed in Section II, above, natural control variables are lags of growth itself: for example, if lagged growth positively affects current growth rates and is positively correlated with current interest rates, then the baseline results may understate the effect of monetary policy. Similary, if lagged inflation rates capture some of the effect of lagged interest rates on output growth, they may reduce the negative effect of current interest rates. As frequently exploited in the literature, covariates may also help to reduce the bias from forward-looking monetary policy. They should thereby yield more negative OLS estimates, and reduce the difference between OLS and IV.

The results including the first four lags of real output growth and inflation are shown in Columns (4) to (6) of Table 1. Compared to the baseline models in Columns (1) to (3), the more extended specifications show only small differences in OLS estimates, suggesting that past output growth and inflation rates are not strongly correlated with current interest rates or output growth. The differences between the OLS results are never significant,

\footnotetext{
${ }^{28}$ The standard errors in Columns (3) and (6) of Tables 1 and 6 are computed as square root of the differences in variance of IV and OLS estimates. In the case of heteroscedasticity-robust or Newey-West standard errors, this is only an approximation, since the covariance of the coefficients is then only approximately equal to the differences in the variances.
} 
nor do they appear to follow a particular pattern across countries. However, there are some minor differences in the IV estimates; in particular, it appears that inclusion of lags of output growth on average strengthens moderately the estimated IV effect for all countries but Spain and Austria. Note that some heterogeneity in coefficient estimates is to be expected due to sampling variation alone. Thus, we do not put too much weight on occasional or obvious outliers.

Table 2 and Table 3 show a wide range of additional specifications for models pooling all countries using different weights. Since the choice of lags in time series regressions is somewhat arbitrary, we choose to report several specifications for alternative weighting schemes. Rows (B) to $(\mathrm{G})$ vary the combinations of lags of inflation and output growth included in the pooled regression. In so doing, it is possible to allow coefficients other than that on the interest rate to vary by country - for example, the first lag of inflation may be entered separately for each country, while the effect of the interest rate may be constrained to be the same across countries. Rows (H) and (I) allow for different lag coefficients for each country. A quick glance at the table indicates that this additional flexibility of the specification affects the interest rate estimate in only very minor ways. To summarize the information in the table, the last rows also report the mean, median, and standard deviation of an extended set of regression specifications (including additional country-specific lags of variable order for inflation and output growth). In all specifications IV remains more negative than OLS. The effects in Row (A) of Table 3 indicate a reduction in real growth (averaged over the four pooled estimates) of 0.115 percentage points, but the average effects in Row $(\mathrm{G})$ indicate a reduction of 0.15 percentage points would be expected. Overall, if covariates were able to control for the bias arising from forward-looking monetary policy, we would have expected that OLS becomes more negative, and that the difference between OLS and IV declines. Our results suggest the opposite.

Our IV estimates are based on a strong and significant 'first-stage' relationship between 
national and German interest rates underlying the IV estimates (Table 4). This is the fundamental relationship providing us with quasi-experimental variation in interest rates. Most countries have a first-stage coefficient of at least .8. However, several countries, including Great Britain, Spain, and Switzerland have first-stage coefficients on the German interest rate significantly below unity. Moreover, Norway, Spain, and Sweden's coefficients are between .5 and .6. Thus, it does not appear that our first-stage relationship is systematically biased towards unity. ${ }^{29}$ Not surprisingly, some of the countries with low first-stage coefficients either were never part of the EMS or joined late. The remaining columns of Table 4 again include up to four lags of output growth and inflation. Additional variables control for co-movements in interest rates driven by common pattern of output shocks and inflation. On average, including lags of inflation and output growth reduces the first-stage coefficient. Lags of output growth tend to increase the first-stage coefficient, while lags of inflation tend to reduce it. This would be expected if lagged inflation partially captures the influence of past interest rates. However, for most countries the differences are not significant. The exceptions are Great Britain, Italy, and Sweden, neither of which we would have thought to be particularly correlated with the German economy. To directly assess the affects of changes in specifications, Table 5 summarizes a wide variety of different specifications for first-stage regression models pooling all countries with alternative weights. The largest pooled estimate is .91, the smallest is .69, and most pooled first-stage coefficients are between .75 and .8. We conclude that German monetary policy appears to be a strong and robust determinant of interest rates for the countries included in our sample.

\footnotetext{
${ }^{29}$ Given the range of estimated coefficients, some significantly below unity, the limited time range, and the partial presence of capital controls during the period of study we do not believe we are subject to the critique raised by Shambaugh (2004) discussed in Section 1. However, we ran several tests for nonstationarity in interest rates and cointegration which are summarized in Appendix Table 4. Overall, although we do not find that interest rates have unambiguous stochastic trends, for some specifications we cannot reject a unit root. However, for those countries we also find that the interest rate exhibits a cointegrating relationship with Germany. For example this can be seen for Great Britain, the Netherlands, or Austria in the case of the standard Dickey-Fuller test for specifications with four lags of output growth and inflation as control variables.
} 
To summarize the differences in IV estimates we explore the relationship between our IV estimates and proxies for the approximate bias (cf. Equation (6)). A simple way to represent the relationship between these estimates and the relevant fundamentals suggested by Equation (6) is shown in Figure 1, which is based on the results from Table 1. Figure 1(a) plots the relationship between the IV estimates and the fraction of GDP due to trade with Germany. As predicted, the IV estimates become less negative the more important a country's trade with Germany is relative to its total output. ${ }^{30}$ Taken at face value, the relationship suggests that a country with no economic ties to Germany - or in other words, the "ideal" country in terms of the assumptions undergirding our identification strategywould have an IV coefficient of roughly -0.15. Figure 1(b) shows how IV estimates are more negative for countries whose currencies were more volatile viz. the German Mark. This result confirms the intuition that a more flexible exchange rate regime allowed countries more monetary independence. Hence the use of the German rate as an instrument picks up more exogenous monetary shocks in the domestic country.

The differences across countries carry over to the gap between OLS and IV estimates. The OLS-IV differences, shown in the third and sixth columns of Table 1, are positive and greater for larger countries. Based on the foregoing, we would also expect it to be larger for countries that are farther from Germany, are less dependent on trade with Germany, and have a more volatile bilateral exchange rate. This is shown in Figure 1(c) and 1(d). Although the cross-country heterogeneity in the OLS-IV difference is greater than that of the IV estimates, the correlations are as expected. The difference is (i) increasing with distance (not shown), (ii) decreasing with the trade to GDP ratio [Fig. 1(c)], and (iii) increasing with exchange rate volatility [Fig. $1(\mathrm{~d})] .^{31}$ These correlations confirm the predictions of

\footnotetext{
${ }^{30} \mathrm{We}$ also experimented using distance to Germany as a proxy for the amount of trade. The IV estimates (the difference between OLS and IV) become more negative (more positive) with distance, as expected, but the relationship is weaker. Given that distance is an imperfect measure of economic integration, we prefer the trade to GDP ratio as proxy for the similarity of output shocks.

${ }^{31}$ Again, the relationship with distance is not overwhelmingly strong, though this is in part driven by
} 
our simple representation of monetary policy decisions summarized in Equation (6), and suggest the gap between IV and OLS reflects at least partially the degree of endogeneity in monetary policy. However, in contrast to the results in Figure 1, there do not appear to be systematic differences between countries in the covariance of home country interest rates with the German interest rate viz. trade to GDP ratio or exchange rate volatility. Note that we would not have necessarily expected any systematic difference, since countries who had the option for more independence may still have an incentive to tie themselves to the German rate for other reasons (e.g., to foster convergence in the process of European integration).

We draw two main conclusions from the results presented in Tables 1 to 5. First, the differences between the OLS and IV estimates are large and systematic across countries, indicating that there may be a substantial component of monetary policy that is forwardlooking. Inclusion of lags of output growth and inflation does not appear to help to account for information differentials between central banks and the public. Second, the differences between OLS and IV appears to be an informative measure of the degree of endogeneity in monetary policy as suggested by the simple model of forward-looking monetary policy outlined in the first section. This suggests IV estimates are less biased than OLS estimates the less economically integrated a country is Germany (e.g., as measured by direct trade links), and the more flexible is its exchange rate regime vis-a-vis the German Mark. These correlations reinforce our view that the gap between OLS and IV estimates can be interpreted as evidence for the potential scope of endogeneity of monetary policy.

On average, OLS suggests that a 5 percentage point increase in nominal interest rates leads to decline in annual real GDP growth of 0.5 to 1 percentage points. Using German interest rates as an instrument, the effect rises to 2 to 3 percentage points, a threefold increase. These results are robust to a wide range of specification checks, and are systematic Great Britain (GBR), which is quite close to Germany as measured. 
across countries as suggested by a variety of weighting procedures.

A corollary to these findings is that larger countries should exhibit a greater inflationary bias since they were generally less dependent on Germany economically and had more discretion viz. their exchange rate regime. This prediction is borne out by the results of Table 1, with the exception of a small bias in France (which has followed German monetary policy quite closely specially during the EMS), and large biases in Norway and Switzerland. Given the large number of estimates we present these may partly represent outliers due to sampling variation. Overall, the results are consistent with the belief that smaller open countries may have less scope to conduct independent monetary policy. ${ }^{32}$

\section{Sensitivity Analysis: EMS-Period, Outliers, Dynamics}

The European Monetary System came into effect in 1979 and committed countries to keep their exchange rates within bands of the German rate. This should have increased the role of leadership of the Bundesbank, and further constrained the monetary policy actions of member countries. This strengthened the mechanism we exploit in our identification strategy, and thus it is important to see whether the results are confirmed in the EMS-period. On the one hand, by further constraining countries' monetary policy choices, we expect the EMS to have led to more negative OLS estimates of the effect of interest rates on growth. On the other hand, von Hagen and Fratianni (1990) speculate that the Bundesbank itself may have become more lenient on inflation, since inflation's negative consequences for the German economy would be partially exported to the other countries under fixed exchange rates. This would imply lower IV estimates, since German monetary policy may have become more endogenous.

Table 6 shows the baseline regression for the EMS era (that is, 1979 to the present).

\footnotetext{
${ }^{32}$ For larger countries, the option for discretionary policy may lead to an inflationary bias. Thus, they should face a greater interest in binding themselves to the stricter monetary regime of the German central bank. This is beyond the scope of this paper.
} 
Overall, the results strongly confirm those of Table 1; with or without lags of growth and inflation IV estimates are systematically more negative than OLS estimates, and more so for larger countries. The differences between the EMS period and the full sample are small but as expected. Most countries experience a small increase in the magnitude of OLS coefficients with the exception of Austria and the UK (for the specification with lags). Similarly, most countries see a slight reduction in the size of IV estimates with the exception of the UK. The pooled estimates (not shown) summarize this result. They show an increase in the OLS estimate of the effect of interest rates on growth from -.03 to -.0413 percentage points for constant GDP weights (the change is not statistically significant). Conversely, the pooled IV estimates display a decline in magnitude from -.1209 to -.0939. ${ }^{33}$ These changes are consistent with the hypothesis that monetary policy has become less endogenous in the follower countries and more endogenous in Germany since 1979. This is confirmed by a separate OLS regression for Germany. The coefficient on German nominal interest rate in a regression of quarterly growth rates of GDP drops from -0.073 to -.036, or from -.064 to zero when lags are included (although standard errors are again large).

The first-stage coefficients for most countries and for the pooled specifications (not shown) also tend to reflect the impact of the EMS. There has been an increase in the effect of German interest rates for several countries in our sample. For example Austria's coefficient is no longer significantly different from one, which is not surprising given that Austria effectively surrendered its monetary policy making decisions to Germany during the EMS. Similarly, we see increases for Italy and Spain, as would be expected, but also for the Netherlands. Only the UK has a smaller first-stage coefficient for some specifications. The coefficients from the pooled specifications increase on average from about .85 (see Row (A) in Table 5) to about 1 without control variables, and from about .7 (see Row $(\mathrm{G})$ in Table 5) to .82 for a more

\footnotetext{
${ }^{33}$ Including four lags of growth and inflation, the results are -.0346 vs. -.0203 for OLS and -.1353 vs. .10 for IV.
} 
conservative specification. The role of observable characteristics indicate that the increases are partly driven by convergence in growth and inflation. However, the main conclusion is robust to lags of output growth and inflation as controls. Thus, at least part of the increase in the first-stage relationships is a genuine policy change.

As noted in Section II, above, estimates for the static model of equations (2) and (5) are a reduced-form parameter for the stance of monetary policy over the recent past. Specifically, if there are lagged effects of nominal interest rates on output growth, the results in Tables $1,2,3$, and 6 can be interpreted as the weighted sum of the impact of current and lagged interest rates (see equations (15) and (16)). The differences in the point estimates across countries could thus be partly explained by the accumulation of differential effects over time and differences in the persistence of interest rates.

As a check on our results, we also ran a dynamic specification including lagged home country interest rates, assuming that lagged interest rates are predetermined. This assumption is tenuous, and would be violated if the central bank were able to accurately estimate output growth more than one period ahead. However, if the assumption were true and if past interest rates had a negative effect on output growth and a positive effect on current interest rates, we would expect inclusion of lagged interest rates to lower the coefficient on current interest rates both in OLS and IV regressions.

The data cannot identify effects for single countries with any degree of precision. For the pooled specifications, we find that inclusion of lagged interest rates (one or four lags) leads to differences in OLS estimates of unclear sign - if all countries are included OLS is more negative, but if only countries with complete data are included, it is less negative. In the first-stage, inclusion of lagged own interest rates reduces the coefficient on the instrument considerably, consistent with a positive correlation of current and lagged interest rates within and across countries. However, IV estimates turn these results upside down - including lagged interest rates leads to significantly positive effects of past interest rates on output 
growth with stronger negative effects of current rates. This suggests that lagged interest rates may be endogenous as well, consistent with monetary policy actions with a horizon of several quarters. Unfortunately, as suggested in Section II, the lags of German interest rates are too persistent to provide separate instruments for lags of followers' interest rates, and thus we cannot move beyond this point.

We also conduct some robustness checks. Figures A1 and A2 present leverage plots for each country for regressions with no output growth lags. The leverage is calculated as follows. We re-run the OLS and IV regressions, dropping an observation each period. We record the estimated interest rate coefficient, and then subtract the estimated interest rate coefficient from regressions using the whole sample (in this case, the estimates from Table 1). This is done for each period, so a point on the figure corresponds to the period where the data point has been dropped. The smaller the leverage the better. In examining the plots, the leverage coefficients are generally close to zero for most countries. Austria, the Netherlands and Sweden are exceptions. Not surprisingly, for these countries the OLS-IV difference is not significantly different from zero.

\section{Conclusion}

We have presented a sequence of simple estimates of the effect of monetary policy on real output growth, ranging from least squares contrasts to instrumental variables estimates. The identification strategy we have pursued attempts to exploit the fact that monetary policymakers may sometimes have competing goals. In particular, since the breakdown of the Bretton-Woods system, many European central banks have followed the leadership of the Bundesbank in setting monetary policy to stabilize their exchange and inflation rates. Using quarterly German nominal interest rates as an instrument for other European countries' nominal interest rates, we estimate that the causal effect of a 5 percentage point increase in nominal interest rates is a contraction in annual real growth of 2 to 3 percentage points. 
This is in contrast to naïve OLS estimates, which suggest a more modest contraction of 0.5 to 1 percentage points.

The primary threat to the econometric validity of our IV estimates is the potential for economic shocks common to the European community. Under a common shocks hypothesis, our IV estimates will be too conservative, in the sense of being biased towards OLS. Since our IV estimates are in fact substantially larger than our OLS estimates, we view our estimates as consistent with fairly decisive impacts of monetary policy on real output.

The primary threat to the economic relevance of our IV estimates is that, due to the high degree of persistence of interest rates, it is difficult to tailor our approach to estimate the dynamic effects of monetary policy. However, as shown above, in a dynamic model, our estimates should be interpreted as a weighted average of the past effects of monetary policy on the economy, with weights of the autocovariances of interest rates. Together, these econometric and economic arguments persuade us that our IV estimates are potentially conservative estimates of the economic consequences of an episode of monetary policy tightening.

The difference between OLS and IV estimates may be interpreted as a measure of the endogeneity component of monetary authority actions. We report two key findings regarding the OLS-IV difference. First, we find that the difference is unaffected by the inclusion of lagged values of GDP growth or inflation as control variables. This finding may be controversial, since it implies that traditional controls for the history of the system are not rich enough to capture the information available to central bankers. This suggests the relevance of the recent extensions of the VAR approach to control variables of extremely high dimension (see, for example, Bernanke, Boivin and Eliasz 2005).

Second, we use the OLS-IV difference to directly test for the presence of bias in simple estimates, by relating the size of the bias to economic conditions affecting monetary policy. We show that the difference is decreasing with respect to the economic closeness between a country and Germany, as measured by physical distance and trade with Germany. We 
also show that the difference is increasing with exchange rate volatility vis-a-vis the German Mark. Finally, we find that during the period of pegged exchange rates under the European Monetary System, IV estimates of the effect of monetary policy, as well as the OLS-IV difference, are smaller than during the post-1973 period as a whole.

We believe the direct focus of IV on exogenous variation in interest rates and the transparency of the identifying assumptions underlying an IV estimation strategy have the potential to generate substantial insight into the relationship between monetary policy and the real economy. It is clear that such an approach is not without drawbacks; for example, the applicability of our approach to other macroeconomic settings hinges on appropriate instruments, which may simply not be available. However, we view a 'natural experiments' approach as a potentially useful diagnostic and research tool in macroeconomic settings that could complement existing approaches. 


\section{Appendix A}

This appendix compares analytically the bias of IV and OLS when the instrument is not quite clean due to correlation of output shocks. Let $C\left[z_{t}, u_{t} \mid W_{t-1}\right] \equiv a$. Then write

$$
\begin{gathered}
\hat{\theta}_{O L S} \stackrel{p}{=} \theta+\frac{\beta_{3} a+C\left[\eta_{t}, u_{t} \mid W_{t-1}\right]}{V\left[i_{t} \mid W_{t-1}\right]} \\
\hat{\theta}_{I V} \stackrel{p}{=} \theta+\frac{a}{C\left[z_{t}, i_{t} \mid W_{t-1}\right]} .
\end{gathered}
$$

Because the parameter $a$ is involved in both expressions, (7) and (8) imply a relationship between the bias of the OLS and IV estimators, notated $B_{O L S}$ and $B_{I V}$, respectively. Specifically, because $\beta_{3}=C\left[z_{t}, i_{t} \mid W_{t-1}\right] / V\left[z_{t} \mid W_{t-1}\right]$, we have

$$
\begin{aligned}
B_{O L S} & =\frac{C\left[z_{t}, i_{t} \mid W_{t-1}\right]}{V\left[z_{t} \mid W_{t-1}\right]} \frac{a}{V\left[i_{t} \mid W_{t-1}\right]}+\frac{C\left[\eta_{t}, u_{t} \mid W_{t-1}\right]}{V\left[i_{t} \mid W_{t-1}\right]} \\
& =\frac{C\left[z_{t}, i_{t} \mid W_{t-1}\right]}{V\left[i_{t} \mid W_{t-1}\right]} \frac{C\left[z_{t}, i_{t} \mid W_{t-1}\right]}{V\left[z_{t} \mid W_{t-1}\right]} B_{I V}+\frac{C\left[\eta_{t}, u_{t} \mid W_{t-1}\right]}{V\left[i_{t} \mid W_{t-1}\right]} \\
& \equiv \rho^{2} B_{I V}+b,
\end{aligned}
$$

where $\rho$ denotes the correlation between $z_{t}$ and $i_{t}$ conditional on $W_{t-1}$. Under what conditions will least squares do worse than instrumental variables? Using equation (9), we see that

$$
B_{O L S}>B_{I V} \quad \Longleftrightarrow \quad B_{I V}<b /\left(1-\rho^{2}\right) .
$$

since $1-\rho^{2}>0$ by the Schwartz inequality. The key term in the inequality in (9) is thus $b$, which should be approximately equal to the bias in a least squares estimate of the impact of monetary policy on the real economy using data on Germany, $B_{O L S}^{*}=$ $C\left[z_{t}, u_{t}^{*} \mid W_{t-1}^{*}\right] / V\left[z_{t} \mid W_{t-1}^{*}\right]$ (we presume that the relationship between German interest rates and output may be modeled by equations (2) and (5) without the instrument $z_{t}$ ). To further explore the bias, consider the auxiliary population regression

$$
u_{t}=\delta u_{t}^{*}+\omega_{t}
$$

where $u_{t}^{*}$ are German output shocks in the German analogue to equation (2). Because this is a population projection, $\omega_{t}$ is the portion of home country output shocks that is orthogonal to German output shocks. We assume that in addition to this, $\omega_{t}$ is orthogonal to German interest rates, $z_{t}$ (we find this quite plausible, but it is a necessary assumption). This allows us to use Equation (11) to characterize the bias of the IV estimator as

$$
B_{I V}=\delta \frac{C\left[z_{t}, u_{t}^{*} \mid W_{t-1}\right]}{C\left[z_{t}, i_{t} \mid W_{t-1}\right]}=\frac{\delta}{\beta_{3}} \frac{C\left[z_{t}, u_{t}^{*} \mid W_{t-1}\right]}{V\left[z_{t} \mid W_{t-1}\right]} \equiv \frac{\delta}{\beta_{3}} \widetilde{B}_{O L S}^{*} \approx \frac{\delta}{\beta_{3}} B_{O L S}^{*} \approx \frac{\delta}{\beta_{3}} b,
$$


To gain intuition, formally treat the approximation in (12) as an equality. Then note that

$$
B_{I V}<\frac{b}{1-\rho^{2}} \quad \Longleftrightarrow \quad \frac{\delta}{\beta_{3}} b<\frac{1}{1-\rho^{2}} b \quad \Longleftrightarrow \quad \delta<\frac{\beta_{3}}{1-\rho^{2}},
$$

Empirically, $\beta_{3}$ is close to 0.8 and $\rho$ is close to 0.4 , leading the right hand side of (13) to be over $0.95 .{ }^{34}$ Because output shocks are unlikely to be correlated more than moderately, this leads to a fairly firm expectation that IV estimates will be less biased than OLS.

It is also possible to treat the approximation in (12) as an inequality. Specifically, it seems likely (although in principle not assured) that the bias in a German OLS estimate is reduced by inclusion of German control variables rather than foreign country controls. That would mean that $\widetilde{B}_{O L S}^{*}>B_{O L S}^{*}$. Moreover, since Germany is widely believed to have had a more effective central bank than most countries over this period, it is expected that $B_{O L S}^{*}>B_{O L S}$, i.e., that Germany's monetary policy was more forward-looking than that of other European countries. This leads to the the inequality chain $b<B_{O L S}^{*}<\widetilde{B}_{O L S}^{*}$. Combining these ideas, we see that

$$
B_{I V}<\frac{b}{1-\rho^{2}} \quad \Longleftrightarrow \quad \frac{\delta}{\beta_{3}} \widetilde{B}_{O L S}^{*}<\frac{1}{1-\rho^{2}} b \quad \Longleftrightarrow \quad \delta<\frac{b}{\widetilde{B}_{O L S}^{*}} \frac{\beta_{3}}{1-\rho^{2}}
$$

which is a slightly attenuated version of the inequality in (13).

\section{Appendix B}

This appendix demonstrates the probability limit of our reduced form parameter under a dynamic data-generating process (DGP). Suppose that in place of (2) the DGP is

$$
y_{t}=\alpha_{0}+\theta_{0} i_{t}+\theta_{1} i_{t-1}+\ldots+\theta_{p} i_{t-p}+\phi_{1}^{\prime} W_{t-1}+u_{t}
$$

The probability limits are

$$
\begin{gathered}
\hat{\theta}_{O L S} \stackrel{p}{=} \theta_{0}+\theta_{1} \gamma_{1}+\theta_{2} \gamma_{2}+\ldots+\theta_{p} \gamma_{p}+\frac{\beta_{3} C\left[z_{t}, u_{t} \mid W_{t-1}\right]+C\left[\eta_{t}, u_{t} \mid W_{t-1}\right]}{V\left[i_{t} \mid W_{t-1}\right]} \\
\hat{\theta}_{I V} \stackrel{p}{=} \theta_{0}+\theta_{1} \gamma_{1}^{I V}+\theta_{2} \gamma_{2}^{I V}+\ldots+\theta_{p} \gamma_{p}^{I V}+\frac{C\left[z_{t}, u_{t} \mid W_{t-1}\right]}{C\left[z_{t}, i_{t} \mid W_{t-1}\right]}
\end{gathered}
$$

where $\gamma_{j}=C\left[i_{t}, i_{t-j} \mid W_{t-1}\right] / V\left[i_{t} \mid W_{t-1}\right], j=1,2, \ldots, p$ are the autocovariances of interest rates, and $\gamma_{j}^{I V}=C\left[z_{t}, i_{t-j} \mid W_{t-1}\right] / C\left[z_{t}, i_{t} \mid W_{t-1}\right]$ are the instrumental variable analogues.

Consider briefly the interpretation of the summary parameter $\theta \equiv \theta_{0}+\theta_{1} \gamma_{1}+\ldots+\theta_{p} \gamma_{p}$. The parameter summarizes (i) the instantaneous effect of monetary policy on the real economy, $\theta_{0}$, and (ii) the historical effect of monetary policy on the real economy, or $\theta_{j}$ for $j=1,2, \ldots p$. The weight $\gamma_{j}$ applied to the historical influence of monetary policy has a

\footnotetext{
${ }^{34}$ Clearly both $\beta_{3}$ and $\rho$ will vary by country; we refer to pooled estimates of their magnitudes.
} 
natural interpretation - it measures the extent to which a monetary tightening in period $t$ predicts that monetary policy was tight in period $t-j$. In short, the summary parameter $\theta$ measures the general effect of an episode of tight monetary policy of a given magnitude. Thus, while our approach does not allow us to trace out the entire dynamic effect of monetary policy on the real economy, it does allow us to identify a parameter of interest to policymakers.

Importantly, the implicit OLS and IV weighting functions are (under a mild assumption) equal - that is, $\gamma_{j}=\gamma_{j}^{I V}$. This follows immediately from a few lines of algebra. Linearly project the German interest rate onto the national interest rate for period $t$, and plug these linear projections into the definition of $\gamma_{j}^{I V}$. The "mild assumption" mentioned holds that the residual from this projection is orthogonal to lagged home country interest rates, which we view as innocuous since the projection residual is by definition orthogonal to current home country interest rates.

\section{References}

Alesina, Alberto and Robert J. Barro, "Currency Unions," Quarterly Journal of Economics, May 2002, $117(2), 409-436$.

Andersen, Leonall C. and Jerry L. Jordon, "Monetary and Fiscal Actions: A Test of Their Relative Importance in Economic Stabilization," The Federal Reserve Bank of St. Louis Review, November 1968, pp. 11-24.

Angrist, Joshua D. and Alan B. Krueger, "Does Compulsory School Attendance Affect Schooling and Earnings?," Quarterly Journal of Economics, November 1991, 106 (4), 979-1014.

Barro, Robert, "Interest-Rate Targeting," Journal of Monetary Economics, 1988, 23, 3-30.

Barro, Robert J. and David B. Gordon, "A Positive Theory of Monetary Policy in a Natural Rate Model," Journal of Political Economy, August 1983, 91 (4), 589-610.

Bayoumi, Tamim and Barry Eichengreen, "Shocking Aspects of European Monetary Unification," in Fransisco Torres and Francesco Giavazzi, eds., Shocking Aspects of European Monetary Unification, Cambridge: Cambridge University Press, 1993, pp. 193-240.

Benigno, Gianluca, "Real Exchange Rate Persistence and Monetary Policy Rules," Journal of Monetary Economics, April 2004, 51 (3), 473-502.

Bernanke, Ben, "Alternative Explanations of the Money-Income Correlation," Carnegie Rochester Conference Series on Public Policy, Autumn 1986, (0), 49-99.

Bernanke, Ben S. and Alan S. Blinder, "The Federal Funds Rate and the Channels of Monetary Transmission," American Economic Review, September 1992, 82 (4), 902921.

and Ilian Mihov, "The Liquidity Effect and Long-Run Neutrality," Carnegie Rochester Conference Series on Public Policy, December 1998, 49, 149-194. 
and Jean Boivin, "Monetary Policy in a Data-Rich Environment," Journal of Monetary Economics, 2004, 50 (3), 525-546.

and Piotr Eliasz, "Measuring Monetary Policy: A Factor Augmented Vector Autoregressive (FAVAR) Approach," Quarterly Journal of Economics, February 2005, $120(1)$.

Blanchard, Olivier J. and Mark Watson, Are All Business Cycles Alike?, Chicago, Il: University of Chicago Press, 1986.

Boivin, Jean and Serena Ng, "Are More Data Always Better for Factor Analysis?," 2003. NBER Working Paper \# 9829 (forthcoming, Journal of Econometrics).

Christiano, Lawrence J., Martin Eichenbaum, and Charles L. Evans, "Monetary Policy Shocks: What Have We Learned and to What End?," in John B. Taylor and Micheal Woodford, eds., Handbook of Macroeconomics, Vol. 1A, New York: North-Holland, Elsevier, 1999, chapter 2, pp. 65-148.

Clarida, Richard and Mark Gertler, "How the Bundesbank Conducts Monetary Policy," in C. Romer and D. Romer, eds., Reducing Inflation: Motivation and Strategy, Chicago, Il: University of Chicago Press, 1997.

, Jordi Galí, and Mark Gertler, "Monetary Policy Rules in Practice: Some International Evidence," European Economics Review, June 1998, 42 (6), 1033-1068.

, and _ _ "Monetary Policy Rules and Macroeconomic Stability: Evidence and Some Theory," The Quarterly Journal of Economics, February 2000, 115 (1), 147-180.

Eichengreen, Barry, "One Money for Europe? Lessons from the US Currency Union," Economic Policy, 1990, 5, 118-87.

Engel, Charles and Kenneth D. West, "Taylor Rules and the Deutschmark-Dollar Real Exchange Rate," 2004. Mimeo, University of Wisconsin.

Fleming, J. Marcus, "Domestic Financial Policies and Fixed and under Floating Exchange Rates," I.M.F. Staff Papers, November 1962, 9, 369-379.

Frankel, Jeffrey A. and Andrew K. Rose, "The Endogeneity of the Optimum Currency Area Criteria," Economic Journal, July 1998, 108 (449), 1009-1025.

Friedman, Milton and Anna J. Schwartz, A Monetary History of the United States, 186701960, Princeton, NJ: Princeton University Press, 1963.

Galí, Jordi and Tommaso Monacelli, "Monetary Policy and Exchange Rate Volatility in a Small Open Economy," Review of Economic Studies, July 2005, 72 (3), 707-734.

Giavazzi, Francesco and Alberto Giovannini, "Models of the EMS: Is Europe a Greater Deutschmark Area?," in Ralph C. Bryant and Richard Portes, eds., Global Macroeconomics, St. Martin's Press New York 1987.

and __ Limiting Exchange Rate Flexibility: The European Monetary System, Cambridge, Mass.: The MIT Press, 1989.

Hamilton, James D., Time Series Analysis, Princeton, NJ: Princeton University Press, 1994. 
Kydland, Finn E. and Edward C. Prescott, "Rules Rather than Discretion: The Inconsistency of Optimal Plans," Journal of Political Economy, June 1977, 85 (3), 473-492.

Mundell, Robert A., "A Theory of Optimum Currency Areas," American Economic Review, September 1961, 51 (4), 657-665.

, "Capital Mobility and Stabilization Policy Under Fixed and Flexible Exchange Rates," Canadian Journal of Economics and Political Science, November 1963, 29 (4), 475-485.

Obstfeld, Maurice, Jay C. Shambaugh, and Alan M. Taylor, "Monetary Sovereignty, Exchange Rates, and Capital Controls: The Trilemma in the Interwar Period," IMF Staff Papers, Special Issue 2004, 51, 75-108.

and ___ "The Trilemma in History: Tradeoffs among Exchange Rates, Monetary Policies, and Capital Mobility," Review of Economics and Statistics, August 2005, $87(3), 423-38$.

Romer, Christina D. and David H. Romer, "Does Monetary Policy Matter? A New Test in the Spirit of Friedman and Schwartz," in Oliver J. Blanchard and Stanley Fischer, eds., NBER Macroeconomics Annual 4, Cambridge, Mass.: The MIT Press, 1989, pp. 121170.

and __ "A New Measure of Monetary Shocks: Derivations and Implications," American Economic Review, September 2004, 94 (4), 1055-1084.

Shambaugh, Jay C., "The Effects of Fixed Exchange Rates on Monetary Policy," Quarterly Journal of Economics, 2004, 119 (1), 301-352.

Sims, Christopher A., "Money, Income, and Causality," American Economic Review, September 1972, 62, 540-552.

_ _ "Comparison of Interwar and Postwar Business Cycles: Monetarism Reconsidered," American Economic Review, May 1980, 70, 250-257.

"Macroeconomics and Reality," Econometrica, January 1980, 48, 1-48.

Stock, James H. and Mark W. Watson, "Vector Autoregressions," Journal of Economic Perspectives, 2001, 15 (4), 101-115.

and ___ "Implications of Dynamic Factor Models for VAR Analysis," 2005. NBER Working Paper \# 11467.

, Jonathan H. Wright, and Motohiro Yogo, "A Survey of Weak Instruments and Weak Identification in Generalized Method of Moments," Journal of Business and Economic Statistics, 2002, 20 (4), 518-530.

Taylor, John B., "Discretion Versus Policy Rules in Practice," Carnegie Rochester Conference Series on Public Policy, December 1993, 93, 195-214.

Tenreyro, Silvana and Robert J. Barro, "Economic Effects of Currency Unions," January 2003. NBER Working Paper No. 9435.

von Hagen, Juergen and Michele Fratianni, "German Dominance in the EMS: Evidence from Interest Rates," Journal of International Money and Finance, 1990, 9, 358-375. 
Watson, Mark, "Vector Autoregressions and Cointegration," in Robert F. Engle and Daniel L. McFadden, eds., The Handbook of Econometrics, Volume 4, New York: Elsevier, 1994, pp. 2843-2915.

Woodford, Michael, Interest and Prices: Foundations of a Theory of Monetary Policy, Princeton, NJ: Princeton University Press, 2003.

Wyplosz, Charles, "EMU: Why and How it Might Happen," Journal of Economic Perspectives, Fall 1997, 11, 3-21. 
Table 1. The Effect of Interest Rates on the Real Economy:

Least Squares and Instrumental Variables Estimates

\begin{tabular}{|c|c|c|c|c|c|c|}
\hline \multirow[b]{2}{*}{ Country } & \multicolumn{3}{|c|}{ No Controls } & \multicolumn{3}{|c|}{ Four Lags of Inflation and Growth } \\
\hline & $\begin{array}{c}(1) \\
\text { OLS }\end{array}$ & $\begin{array}{l}\text { (2) } \\
\text { IV }\end{array}$ & $\begin{array}{c}\text { (3) } \\
\text { OLS-IV } \\
\end{array}$ & $\begin{array}{c}(4) \\
\text { OLS }\end{array}$ & $\begin{array}{l}\text { (5) } \\
\text { IV }\end{array}$ & $\begin{array}{c}6) \\
\text { OLS-IV }\end{array}$ \\
\hline Germany & $\begin{array}{l}-0.073 \\
(0.043) \\
{[0.041]}\end{array}$ & & & $\begin{array}{l}-0.064 \\
(0.048) \\
{[0.049]}\end{array}$ & & \\
\hline Great Britain & $\begin{array}{l}-0.058 \\
(0.031) \\
{[0.036]}\end{array}$ & $\begin{array}{l}-0.197 \\
(0.055) \\
{[0.069]}\end{array}$ & $\begin{array}{c}0.139 \\
(0.046) \\
{[0.060]}\end{array}$ & $\begin{array}{l}-0.059 \\
(0.025) \\
{[0.024]}\end{array}$ & $\begin{array}{l}-0.179 \\
(0.043) \\
{[0.052]}\end{array}$ & $\begin{array}{c}0.120 \\
(0.035) \\
{[0.047]}\end{array}$ \\
\hline France & $\begin{array}{l}-0.015 \\
(0.015) \\
{[0.016]}\end{array}$ & $\begin{array}{l}-0.074 \\
(0.035) \\
{[0.042]}\end{array}$ & $\begin{array}{c}0.059 \\
(0.032) \\
{[0.038]}\end{array}$ & $\begin{array}{l}-0.019 \\
(0.020) \\
{[0.026]}\end{array}$ & $\begin{array}{l}-0.072 \\
(0.035) \\
{[0.032]}\end{array}$ & $\begin{array}{c}0.053 \\
(0.029) \\
{[0.019]}\end{array}$ \\
\hline Italy & $\begin{array}{l}-0.024 \\
(0.018) \\
{[0.020]}\end{array}$ & $\begin{array}{c}-0.129 \\
(0.047) \\
{[0.070]}\end{array}$ & $\begin{array}{c}0.105 \\
(0.043) \\
{[0.067]}\end{array}$ & $\begin{array}{l}-0.034 \\
(0.023) \\
{[0.021]}\end{array}$ & $\begin{array}{l}-0.168 \\
(0.062) \\
{[0.059]}\end{array}$ & $\begin{array}{c}0.134 \\
(0.057) \\
{[0.056]}\end{array}$ \\
\hline Spain & $\begin{array}{l}-0.015 \\
(0.011) \\
{[0.015]}\end{array}$ & $\begin{array}{c}-0.180 \\
(0.078) \\
{[0.131]}\end{array}$ & $\begin{array}{c}0.165 \\
(0.077) \\
{[0.131]}\end{array}$ & $\begin{array}{c}0.002 \\
(0.005) \\
{[0.004]}\end{array}$ & $\begin{array}{l}-0.063 \\
(0.043) \\
{[0.053]}\end{array}$ & $\begin{array}{c}0.066 \\
(0.042) \\
{[0.053]}\end{array}$ \\
\hline Netherlands & $\begin{array}{l}-0.094 \\
(0.034) \\
{[0.029]}\end{array}$ & $\begin{array}{l}-0.145 \\
(0.050) \\
{[0.040]}\end{array}$ & $\begin{array}{c}0.051 \\
(0.036) \\
{[0.028]}\end{array}$ & $\begin{array}{l}-0.087 \\
(0.038) \\
{[0.038]}\end{array}$ & $\begin{array}{l}-0.140 \\
(0.060) \\
{[0.048]}\end{array}$ & $\begin{array}{c}0.052 \\
(0.046) \\
{[0.030]}\end{array}$ \\
\hline Switzerland & $\begin{array}{l}-0.016 \\
(0.041) \\
{[0.046]}\end{array}$ & $\begin{array}{c}-0.130 \\
(0.089) \\
{[0.088]}\end{array}$ & $\begin{array}{c}0.114 \\
(0.079) \\
{[0.074]}\end{array}$ & $\begin{array}{l}-0.015 \\
(0.040) \\
{[0.043]}\end{array}$ & $\begin{array}{l}-0.060 \\
(0.076) \\
{[0.058]}\end{array}$ & $\begin{array}{c}0.044 \\
(0.065) \\
{[0.039]}\end{array}$ \\
\hline Sweden & $\begin{array}{l}-0.055 \\
(0.034) \\
{[0.033]}\end{array}$ & $\begin{array}{l}-0.061 \\
(0.047) \\
{[0.042]}\end{array}$ & $\begin{array}{c}0.006 \\
(0.033) \\
{[0.026]}\end{array}$ & $\begin{array}{l}-0.085 \\
(0.060) \\
{[0.054]}\end{array}$ & $\begin{array}{l}-0.112 \\
(0.076) \\
{[0.071]}\end{array}$ & $\begin{array}{c}0.027 \\
(0.046) \\
{[0.047]}\end{array}$ \\
\hline Belgium & $\begin{array}{l}-0.031 \\
(0.063) \\
{[0.040]}\end{array}$ & $\begin{array}{l}-0.025 \\
(0.131) \\
{[0.079]}\end{array}$ & $\begin{array}{l}-0.006 \\
(0.114) \\
{[0.069]}\end{array}$ & $\begin{array}{l}-0.118 \\
(0.058) \\
{[0.059]}\end{array}$ & $\begin{array}{l}-0.174 \\
(0.136) \\
{[0.141]}\end{array}$ & $\begin{array}{c}0.056 \\
(0.123) \\
{[0.128]}\end{array}$ \\
\hline Austria & $\begin{array}{l}-0.069 \\
(0.085) \\
{[0.055]}\end{array}$ & $\begin{array}{l}-0.065 \\
(0.090) \\
{[0.058]}\end{array}$ & $\begin{array}{l}-0.004 \\
(0.028) \\
{[0.018]}\end{array}$ & $\begin{array}{l}-0.097 \\
(0.070) \\
{[0.074]}\end{array}$ & $\begin{array}{l}-0.072 \\
(0.090) \\
{[0.084]}\end{array}$ & $\begin{array}{l}-0.025 \\
(0.057) \\
{[0.039]}\end{array}$ \\
\hline Norway & $\begin{array}{l}-0.047 \\
(0.066) \\
{[0.050]}\end{array}$ & $\begin{array}{l}-0.175 \\
(0.196) \\
{[0.162]}\end{array}$ & $\begin{array}{c}0.128 \\
(0.184) \\
{[0.154]}\end{array}$ & $\begin{array}{l}-0.093 \\
(0.075) \\
{[0.074]}\end{array}$ & $\begin{array}{l}-0.435 \\
(0.286) \\
{[0.290]}\end{array}$ & $\begin{array}{c}0.342 \\
(0.276) \\
{[0.281]}\end{array}$ \\
\hline Portugal & $\begin{array}{l}-0.025 \\
(0.032) \\
{[0.024]}\end{array}$ & $\begin{array}{l}-0.068 \\
(0.062) \\
{[0.042]}\end{array}$ & $\begin{array}{c}0.044 \\
(0.054) \\
{[0.035]}\end{array}$ & $\begin{array}{l}-0.047 \\
(0.039) \\
{[0.039]}\end{array}$ & $\begin{array}{l}-0.104 \\
(0.083) \\
{[0.059]}\end{array}$ & $\begin{array}{c}0.057 \\
(0.073) \\
{[0.044]}\end{array}$ \\
\hline
\end{tabular}

Notes: The tables gives OLS and IV estimates of the effect of nominal interest rates on quarterly real economic growth. OLS estimates in columns (1) and (4) include four season indicators ("no controls") and four season indicators as well as four lags each of inflation and real economic growth, respectively. IV estimates in columns (2) and (5) use the same controls, but instrument home country interest rates with German interest rates. OLS-IV difference in columns (3) and (6) give the simple difference between the OLS and IV estimates. Standard errors in parentheses are Huber-Eicker-White standard errors and are robust to heteroskedasticity. Standard errors in square braces are fourth-order Newey-West standard errors and are robust to fourth order autocorrelation. 
Table 2. Summarizing Least Squares

\begin{tabular}{|c|c|c|c|c|c|}
\hline & & & Weig & Scheme & \\
\hline & & (1) & (2) & (3) & (4) \\
\hline & Controls & Equal & 2003 GDP (US\$) & $\begin{array}{c}\text { Non-Trade Fraction } \\
\text { of GDP }\end{array}$ & $\begin{array}{c}\text { Volatility, Nominal } \\
\text { Exchange Rate }\end{array}$ \\
\hline (A) & No Controls & $\begin{array}{l}-0.0325 \\
(0.0117) \\
{[0.0102]}\end{array}$ & $\begin{array}{l}-0.0300 \\
(0.0097) \\
{[0.0114]}\end{array}$ & $\begin{array}{l}-0.0318 \\
(0.0117) \\
{[0.0102]}\end{array}$ & $\begin{array}{l}-0.0296 \\
(0.0115) \\
{[0.0103]}\end{array}$ \\
\hline (B) & One Lag of Growth & $\begin{array}{l}-0.0411 \\
(0.0118) \\
{[0.0120]}\end{array}$ & $\begin{array}{l}-0.0319 \\
(0.0101) \\
{[0.0122]}\end{array}$ & $\begin{array}{l}-0.0404 \\
(0.0118) \\
{[0.0121]}\end{array}$ & $\begin{array}{l}-0.0384 \\
(0.0116) \\
{[0.0124]}\end{array}$ \\
\hline (C) & One Lag of Inflation & $\begin{array}{l}-0.0336 \\
(0.0140) \\
{[0.0124]}\end{array}$ & $\begin{array}{l}-0.0262 \\
(0.0107) \\
{[0.0123]}\end{array}$ & $\begin{array}{l}-0.0327 \\
(0.0139) \\
{[0.0124]}\end{array}$ & $\begin{array}{l}-0.0284 \\
(0.0130) \\
{[0.0118]}\end{array}$ \\
\hline (D) & $\begin{array}{l}\text { One Lag of Growth } \\
\text { and Inflation }\end{array}$ & $\begin{array}{l}-0.0379 \\
(0.0138) \\
{[0.0138]}\end{array}$ & $\begin{array}{l}-0.0272 \\
(0.0109) \\
{[0.0129]}\end{array}$ & $\begin{array}{l}-0.0370 \\
(0.0138) \\
{[0.0138]}\end{array}$ & $\begin{array}{l}-0.0329 \\
(0.0130) \\
{[0.0134]}\end{array}$ \\
\hline (E) & Four Lags of Growth & $\begin{array}{l}-0.0411 \\
(0.0123) \\
{[0.0127]}\end{array}$ & $\begin{array}{l}-0.0295 \\
(0.0105) \\
{[0.0121]}\end{array}$ & $\begin{array}{l}-0.0402 \\
(0.0123) \\
{[0.0127]}\end{array}$ & $\begin{array}{l}-0.0361 \\
(0.0121) \\
{[0.0127]}\end{array}$ \\
\hline (F) & Four Lags of Inflation & $\begin{array}{l}-0.0306 \\
(0.0154) \\
{[0.0132]}\end{array}$ & $\begin{array}{l}-0.0211 \\
(0.0113) \\
{[0.0125]}\end{array}$ & $\begin{array}{l}-0.0299 \\
(0.0154) \\
{[0.0132]}\end{array}$ & $\begin{array}{l}-0.0252 \\
(0.0140) \\
{[0.0125]}\end{array}$ \\
\hline (G) & $\begin{array}{l}\text { Four Lags of Growth } \\
\text { and Inflation }\end{array}$ & $\begin{array}{l}-0.0353 \\
(0.0156) \\
{[0.0158]}\end{array}$ & $\begin{array}{l}-0.0203 \\
(0.0120) \\
{[0.0130]}\end{array}$ & $\begin{array}{l}-0.0344 \\
(0.0156) \\
{[0.0158]}\end{array}$ & $\begin{array}{l}-0.0283 \\
(0.0144) \\
{[0.0148]}\end{array}$ \\
\hline (H) & $\begin{array}{l}\text { One Lag of Growth } \\
\text { and Inflation, Different } \\
\text { for each Country }\end{array}$ & $\begin{array}{l}-0.0464 \\
(0.0143) \\
{[0.0154]}\end{array}$ & $\begin{array}{l}-0.0369 \\
(0.0107) \\
{[0.0123]}\end{array}$ & $\begin{array}{l}-0.0456 \\
(0.0143) \\
{[0.0154]}\end{array}$ & $\begin{array}{l}-0.0412 \\
(0.0131) \\
{[0.0142]}\end{array}$ \\
\hline (I) & $\begin{array}{l}\text { Four Lags of Growth } \\
\text { and Inflation, Different } \\
\text { for each Country }\end{array}$ & $\begin{array}{l}-0.0497 \\
(0.0148) \\
{[0.0160]}\end{array}$ & $\begin{array}{l}-0.0374 \\
(0.0109) \\
{[0.0124]}\end{array}$ & $\begin{array}{l}-0.0488 \\
(0.0148) \\
{[0.0160]}\end{array}$ & $\begin{array}{l}-0.0447 \\
(0.0134) \\
{[0.0147]}\end{array}$ \\
\hline & Average Coefficient & -0.0413 & -0.0315 & -0.0405 & -0.0365 \\
\hline & Median Coefficient & -0.0411 & -0.0319 & -0.0404 & -0.0384 \\
\hline & Standard Deviation & 0.0067 & 0.0063 & 0.0067 & 0.0068 \\
\hline
\end{tabular}

Note: Table gives pooled OLS estimates of the impact of nominal interest rates on quarterly real GDP growth for all countries except Germany. Estimation includes the control variables specified under "Controls" and uses country-specific weights described in the column heading. Each estimate includes season indicators fully interacted country indicators. In Columns $(\mathrm{H})$ and $(\mathrm{I})$, lags are chosen separately for each countries using significance levels. Column (1) gives estimates that are equally weighted.

Column (2) gives estimates based on weights that are proportional to a country's 2003 level of GDP in US dollars. Column (3) gives estimates that are weighted by one minus the fraction of a country's GDP that stems from trade with Germany. Column (4) gives estimates that are weighted by the volatility of the nominal exchange rate. The last three rows report the mean, median, and standard deviation of the coefficient estimates in columns (A) to (I) plus additional specifications with different sets of different lags for each countries. Huber-Eicker-White standard errors in parentheses, and fourth-order Newey-West standard errors in square brackets. 
Table 3. Summarizing Instrumental Variables

\begin{tabular}{|c|c|c|c|c|c|}
\hline & & & Weig & Scheme & \\
\hline & & (1) & (2) & (3) & (4) \\
\hline & Controls & Equal & 2003 GDP (US\$) & $\begin{array}{c}\text { Non-Trade Fraction } \\
\text { of GDP } \\
\end{array}$ & $\begin{array}{c}\text { Volatility, Nominal } \\
\text { Exchange Rate }\end{array}$ \\
\hline (A) & No Controls & $\begin{array}{l}-0.1073 \\
(0.0242) \\
{[0.0215]}\end{array}$ & $\begin{array}{l}-0.1209 \\
(0.0214) \\
{[0.0274]}\end{array}$ & $\begin{array}{l}-0.1083 \\
(0.0245) \\
{[0.0220]}\end{array}$ & $\begin{array}{l}-0.1150 \\
(0.0260) \\
{[0.0241]}\end{array}$ \\
\hline (B) & One Lag of Growth & $\begin{array}{l}-0.1297 \\
(0.0250) \\
{[0.0239]}\end{array}$ & $\begin{array}{l}-0.1321 \\
(0.0232) \\
{[0.0301]}\end{array}$ & $\begin{array}{l}-0.1315 \\
(0.0254) \\
{[0.0246]}\end{array}$ & $\begin{array}{l}-0.1419 \\
(0.0270) \\
{[0.0276]}\end{array}$ \\
\hline (C) & One Lag of Inflation & $\begin{array}{l}-0.1166 \\
(0.0266) \\
{[0.0230]}\end{array}$ & $\begin{array}{l}-0.1286 \\
(0.0239) \\
{[0.0298]}\end{array}$ & $\begin{array}{l}-0.1175 \\
(0.0269) \\
{[0.0235]}\end{array}$ & $\begin{array}{l}-0.1228 \\
(0.0284) \\
{[0.0259]}\end{array}$ \\
\hline (D) & $\begin{array}{l}\text { One Lag of Growth } \\
\text { and Inflation }\end{array}$ & $\begin{array}{l}-0.1349 \\
(0.0271) \\
{[0.0254]}\end{array}$ & $\begin{array}{l}-0.1381 \\
(0.0252) \\
{[0.0319]}\end{array}$ & $\begin{array}{l}-0.1366 \\
(0.0275) \\
{[0.0260]}\end{array}$ & $\begin{array}{l}-0.1460 \\
(0.0291) \\
{[0.0293]}\end{array}$ \\
\hline (E) & Four Lags of Growth & $\begin{array}{l}-0.1362 \\
(0.0253) \\
{[0.0250]}\end{array}$ & $\begin{array}{l}-0.1262 \\
(0.0232) \\
{[0.0291]}\end{array}$ & $\begin{array}{l}-0.1379 \\
(0.0258) \\
{[0.0257]}\end{array}$ & $\begin{array}{l}-0.1439 \\
(0.0278) \\
{[0.0284]}\end{array}$ \\
\hline (F) & Four Lags of Inflation & $\begin{array}{l}-0.1247 \\
(0.0305) \\
{[0.0261]}\end{array}$ & $\begin{array}{l}-0.1331 \\
(0.0258) \\
{[0.0318]}\end{array}$ & $\begin{array}{l}-0.1258 \\
(0.0309) \\
{[0.0267]}\end{array}$ & $\begin{array}{l}-0.1315 \\
(0.0324) \\
{[0.0296]}\end{array}$ \\
\hline (G) & $\begin{array}{l}\text { Four Lags of Growth } \\
\text { and Inflation }\end{array}$ & $\begin{array}{l}-0.1524 \\
(0.0313) \\
{[0.0301]}\end{array}$ & $\begin{array}{l}-0.1353 \\
(0.0266) \\
{[0.0323]}\end{array}$ & $\begin{array}{l}-0.1543 \\
(0.0318) \\
{[0.0309]}\end{array}$ & $\begin{array}{l}-0.1588 \\
(0.0339) \\
{[0.0341]}\end{array}$ \\
\hline (H) & $\begin{array}{l}\text { One Lag of Growth } \\
\text { and Inflation, Different } \\
\text { for each Country }\end{array}$ & $\begin{array}{l}-0.1322 \\
(0.0299) \\
{[0.0281]}\end{array}$ & $\begin{array}{l}-0.1228 \\
(0.0222) \\
{[0.0231]}\end{array}$ & $\begin{array}{l}-0.1335 \\
(0.0303) \\
{[0.0286]}\end{array}$ & $\begin{array}{l}-0.1381 \\
(0.0309) \\
{[0.0299]}\end{array}$ \\
\hline (I) & $\begin{array}{l}\text { Four Lags of Growth } \\
\text { and Inflation, Different } \\
\text { for each Country }\end{array}$ & $\begin{array}{l}-0.1338 \\
(0.0301) \\
{[0.0281]}\end{array}$ & $\begin{array}{l}-0.1231 \\
(0.0223) \\
{[0.0232]}\end{array}$ & $\begin{array}{l}-0.1352 \\
(0.0305) \\
{[0.0287]}\end{array}$ & $\begin{array}{l}-0.1405 \\
(0.0311) \\
{[0.0298]}\end{array}$ \\
\hline & Average Coefficient & -0.1306 & -0.1282 & -0.1317 & -0.1376 \\
\hline & Median Coefficient & -0.1322 & -0.1282 & -0.1335 & -0.1405 \\
\hline & Standard Deviation & 0.0106 & 0.0055 & 0.0109 & 0.0109 \\
\hline
\end{tabular}

Note: Table gives pooled IV estimates of the impact of nominal interest rates on quarterly real GDP growth for all countries using German 'nominal interest rates as an instrument for home country interest rates. See Table 2 for additional details on table interpretation. 
Table 4. Comovements in European Nominal Interest Rates

(1)

(2)

(3)

(4)

(5)

\begin{tabular}{|c|c|c|c|c|c|}
\hline Country & No Controls & $\begin{array}{l}\text { One Lag of } \\
\text { Growth }\end{array}$ & $\begin{array}{c}\text { One Lag of } \\
\text { Growth and } \\
\text { Inflation } \\
\end{array}$ & $\begin{array}{c}\text { Four Lags of } \\
\text { Growth } \\
\end{array}$ & $\begin{array}{c}\text { Four Lags of } \\
\text { Growth and } \\
\text { Inflation } \\
\end{array}$ \\
\hline Great Britain & $\begin{array}{c}0.750 \\
(0.126) \\
{[0.210]}\end{array}$ & $\begin{array}{c}0.764 \\
(0.140) \\
{[0.206]}\end{array}$ & $\begin{array}{c}0.766 \\
(0.143) \\
{[0.208]}\end{array}$ & $\begin{array}{c}0.957 \\
(0.168) \\
{[0.248]}\end{array}$ & $\begin{array}{l}1.147 \\
(0.153) \\
{[0.218]}\end{array}$ \\
\hline France & $\begin{array}{l}1.264 \\
(0.247) \\
{[0.315]}\end{array}$ & $\begin{array}{l}1.304 \\
(0.259) \\
{[0.323]}\end{array}$ & $\begin{array}{c}1.121 \\
(0.236) \\
{[0.219]}\end{array}$ & $\begin{array}{l}1.302 \\
(0.248) \\
{[0.318]}\end{array}$ & $\begin{array}{l}1.113 \\
(0.215) \\
{[0.204]}\end{array}$ \\
\hline Italy & $\begin{array}{c}0.950 \\
(0.199) \\
{[0.316]}\end{array}$ & $\begin{array}{c}0.964 \\
(0.211) \\
{[0.324]}\end{array}$ & $\begin{array}{c}0.611 \\
(0.196) \\
{[0.231]}\end{array}$ & $\begin{array}{c}0.957 \\
(0.215) \\
{[0.339]}\end{array}$ & $\begin{array}{c}0.583 \\
(0.165) \\
{[0.187]}\end{array}$ \\
\hline Spain & $\begin{array}{c}0.488 \\
(0.194) \\
{[0.338]}\end{array}$ & $\begin{array}{c}0.421 \\
(0.179) \\
{[0.305]}\end{array}$ & $\begin{array}{c}0.411 \\
(0.181) \\
{[0.276]}\end{array}$ & $\begin{array}{c}0.418 \\
(0.187) \\
{[0.318]}\end{array}$ & $\begin{array}{c}0.441 \\
(0.183) \\
{[0.263]}\end{array}$ \\
\hline Netherlands & $\begin{array}{c}0.870 \\
(0.085) \\
{[0.110]}\end{array}$ & $\begin{array}{c}0.866 \\
(0.091) \\
{[0.113]}\end{array}$ & $\begin{array}{c}0.811 \\
(0.098) \\
{[0.124]}\end{array}$ & $\begin{array}{c}0.877 \\
(0.093) \\
{[0.123]}\end{array}$ & $\begin{array}{c}0.793 \\
(0.105) \\
{[0.146]}\end{array}$ \\
\hline Switzerland & $\begin{array}{c}0.559 \\
(0.122) \\
{[0.243]}\end{array}$ & $\begin{array}{c}0.559 \\
(0.123) \\
{[0.244]}\end{array}$ & $\begin{array}{c}0.635 \\
(0.139) \\
{[0.258]}\end{array}$ & $\begin{array}{c}0.552 \\
(0.128) \\
{[0.253]}\end{array}$ & $\begin{array}{l}0.702 \\
(0.159) \\
{[0.279]}\end{array}$ \\
\hline Sweden & $\begin{array}{l}1.033 \\
(0.075) \\
{[0.104]}\end{array}$ & $\begin{array}{l}1.012 \\
(0.076) \\
{[0.106]}\end{array}$ & $\begin{array}{c}0.820 \\
(0.074) \\
{[0.100]}\end{array}$ & $\begin{array}{c}0.974 \\
(0.082) \\
{[0.114]}\end{array}$ & $\begin{array}{c}0.707 \\
(0.064) \\
{[0.088]}\end{array}$ \\
\hline Belgium & $\begin{array}{l}1.105 \\
(0.200) \\
{[0.254]}\end{array}$ & $\begin{array}{l}1.080 \\
(0.191) \\
{[0.253]}\end{array}$ & $\begin{array}{l}1.080 \\
(0.194) \\
{[0.252]}\end{array}$ & $\begin{array}{c}1.010 \\
(0.201) \\
{[0.309]}\end{array}$ & $\begin{array}{c}0.910 \\
(0.237) \\
{[0.312]}\end{array}$ \\
\hline Austria & $\begin{array}{c}0.838 \\
(0.060) \\
{[0.089]}\end{array}$ & $\begin{array}{c}0.839 \\
(0.061) \\
{[0.091]}\end{array}$ & $\begin{array}{c}0.820 \\
(0.060) \\
{[0.088]}\end{array}$ & $\begin{array}{c}0.833 \\
(0.063) \\
{[0.093]}\end{array}$ & $\begin{array}{c}0.787 \\
(0.063) \\
{[0.093]}\end{array}$ \\
\hline Norway & $\begin{array}{c}0.596 \\
(0.177) \\
{[0.270]}\end{array}$ & $\begin{array}{c}0.573 \\
(0.169) \\
{[0.267]}\end{array}$ & $\begin{array}{c}0.560 \\
(0.174) \\
{[0.268]}\end{array}$ & $\begin{array}{c}0.488 \\
(0.185) \\
{[0.290]}\end{array}$ & $\begin{array}{c}0.495 \\
(0.209) \\
{[0.304]}\end{array}$ \\
\hline Portugal & $\begin{array}{c}1.143 \\
(0.191) \\
{[0.345]}\end{array}$ & $\begin{array}{c}1.125 \\
(0.196) \\
{[0.348]}\end{array}$ & $\begin{array}{c}1.008 \\
(0.191) \\
{[0.263]}\end{array}$ & $\begin{array}{c}1.098 \\
(0.198) \\
{[0.354]}\end{array}$ & $\begin{array}{c}0.912 \\
(0.146) \\
{[0.211]}\end{array}$ \\
\hline
\end{tabular}

Notes: The tables gives OLS estimates of the effect of nominal German interest rates on nominal interest rates for countries specified, controlling for effects specified in column headings in addition to four season indicators. In parentheses are Huber-Eicker-White standard errors, which are robust to heteroskedasticity. In brackets are fourth-order Newey-West standard errors, which are robust to fourth order autocorrelation. 
Table 5. Summarizing the Strength of the First Stage Relationship

\begin{tabular}{|c|c|c|c|c|c|}
\hline & & & Weig & Scheme & \\
\hline & & (1) & (2) & (3) & (4) \\
\hline & Controls & Equal & 2003 GDP (US\$) & $\begin{array}{c}\text { Non-Trade Fraction } \\
\text { of GDP }\end{array}$ & $\begin{array}{c}\text { Volatility, Nominal } \\
\text { Exchange Rate }\end{array}$ \\
\hline (A) & No Controls & $\begin{array}{c}0.8539 \\
(0.0524) \\
{[0.0852]}\end{array}$ & $\begin{array}{c}0.8987 \\
(0.0820) \\
{[0.1252]}\end{array}$ & $\begin{array}{c}0.8529 \\
(0.0544) \\
{[0.0882]}\end{array}$ & $\begin{array}{c}0.8346 \\
(0.0607) \\
{[0.1009]}\end{array}$ \\
\hline (B) & One Lag of Growth & $\begin{array}{c}0.8449 \\
(0.0525) \\
{[0.0854]}\end{array}$ & $\begin{array}{c}0.8981 \\
(0.0844) \\
{[0.1272]}\end{array}$ & $\begin{array}{c}0.8436 \\
(0.0544) \\
{[0.0884]}\end{array}$ & $\begin{array}{c}0.8225 \\
(0.0608) \\
{[0.1010]}\end{array}$ \\
\hline (C) & One Lag of Inflation & $\begin{array}{c}0.7895 \\
(0.0527) \\
{[0.0792]}\end{array}$ & $\begin{array}{c}0.8220 \\
(0.0792) \\
{[0.1120]}\end{array}$ & $\begin{array}{c}0.7883 \\
(0.0545) \\
{[0.0818]}\end{array}$ & $\begin{array}{c}0.7702 \\
(0.0609) \\
{[0.0928]}\end{array}$ \\
\hline (D) & $\begin{array}{l}\text { One Lag of Growth } \\
\text { and Inflation }\end{array}$ & $\begin{array}{c}0.7894 \\
(0.0527) \\
{[0.0794]}\end{array}$ & $\begin{array}{c}0.8340 \\
(0.0813) \\
{[0.1135]}\end{array}$ & $\begin{array}{c}0.7881 \\
(0.0546) \\
{[0.0820]}\end{array}$ & $\begin{array}{c}0.7695 \\
(0.0609) \\
{[0.0929]}\end{array}$ \\
\hline (E) & Four Lags of Growth & $\begin{array}{c}0.8335 \\
(0.0526) \\
{[0.0863]}\end{array}$ & $\begin{array}{c}0.9100 \\
(0.0831) \\
{[0.1270]}\end{array}$ & $\begin{array}{c}0.8316 \\
(0.0546) \\
{[0.0894]}\end{array}$ & $\begin{array}{c}0.8088 \\
(0.0615) \\
{[0.1027]}\end{array}$ \\
\hline (F) & Four Lags of Inflation & $\begin{array}{c}0.7143 \\
(0.0538) \\
{[0.0803]}\end{array}$ & $\begin{array}{c}0.7702 \\
(0.0788) \\
{[0.1124]}\end{array}$ & $\begin{array}{c}0.7129 \\
(0.0557) \\
{[0.0826]}\end{array}$ & $\begin{array}{c}0.6933 \\
(0.0623) \\
{[0.0941]}\end{array}$ \\
\hline (G) & $\begin{array}{l}\text { Four Lags of Growth } \\
\text { and Inflation }\end{array}$ & $\begin{array}{c}0.7100 \\
(0.0538) \\
{[0.0817]}\end{array}$ & $\begin{array}{c}0.8024 \\
(0.0805) \\
{[0.1162]}\end{array}$ & $\begin{array}{c}0.7084 \\
(0.0557) \\
{[0.0842]}\end{array}$ & $\begin{array}{c}0.6900 \\
(0.0626) \\
{[0.0964]}\end{array}$ \\
\hline (H) & $\begin{array}{l}\text { One Lag of Growth } \\
\text { and Inflation, Different } \\
\text { for each Country }\end{array}$ & $\begin{array}{c}0.7684 \\
(0.0543) \\
{[0.0741]}\end{array}$ & $\begin{array}{c}0.8288 \\
(0.0802) \\
{[0.0961]}\end{array}$ & $\begin{array}{c}0.7680 \\
(0.0564) \\
{[0.0767]}\end{array}$ & $\begin{array}{c}0.7624 \\
(0.0647) \\
{[0.0895]}\end{array}$ \\
\hline (I) & $\begin{array}{l}\text { Four Lags of Growth } \\
\text { and Inflation, Different } \\
\text { for each Country }\end{array}$ & $\begin{array}{c}0.7602 \\
(0.0528) \\
{[0.0720]}\end{array}$ & $\begin{array}{c}0.8271 \\
(0.0803) \\
{[0.0963]}\end{array}$ & $\begin{array}{c}0.7596 \\
(0.0548) \\
{[0.0745]}\end{array}$ & $\begin{array}{c}0.7508 \\
(0.0621) \\
{[0.0858]}\end{array}$ \\
\hline & Average Coefficient & 0.7777 & 0.8297 & 0.7766 & 0.7621 \\
\hline & Median Coefficient & 0.7804 & 0.8288 & 0.7805 & 0.7695 \\
\hline & Standard Deviation & 0.0461 & 0.0487 & 0.0462 & 0.0463 \\
\hline
\end{tabular}

Note: Table gives pooled OLS estimates of the impact of German nominal interest rates on nominal interest rates for non-German countries. See Table 2 for additional details on table interpretation. 
Table 6. Baseline OLS and IV Estimates for the EMS Period

\begin{tabular}{|c|c|c|c|c|c|c|}
\hline \multirow[b]{2}{*}{ Country } & \multicolumn{3}{|c|}{ No Controls } & \multicolumn{3}{|c|}{ Four Lags of Inflation and Growth } \\
\hline & $\begin{array}{c}(1) \\
\text { OLS }\end{array}$ & $\begin{array}{l}\text { (2) } \\
\text { IV }\end{array}$ & $\begin{array}{c}\text { (3) } \\
\text { OLS-IV }\end{array}$ & $\begin{array}{c}\text { (4) } \\
\text { OLS }\end{array}$ & $\begin{array}{l}\text { (5) } \\
\text { IV }\end{array}$ & $\begin{array}{c}(6) \\
\text { OLS-IV }\end{array}$ \\
\hline Germany & $\begin{array}{l}-0.036 \\
(0.046) \\
{[0.044]}\end{array}$ & & & $\begin{array}{l}-0.003 \\
(0.071) \\
{[0.058]}\end{array}$ & $\begin{array}{c}-0.003 \\
(0.071) \\
{[0.058]}\end{array}$ & \\
\hline Great Britain & $\begin{array}{l}-0.108 \\
(0.026) \\
{[0.035]}\end{array}$ & $\begin{array}{c}-0.218 \\
(0.054) \\
{[0.070]}\end{array}$ & $\begin{array}{c}0.110 \\
(0.047) \\
{[0.061]}\end{array}$ & $\begin{array}{l}-0.028 \\
(0.042) \\
{[0.039]}\end{array}$ & $\begin{array}{c}-0.252 \\
(0.233) \\
{[0.306]}\end{array}$ & $\begin{array}{c}0.224 \\
(0.230) \\
{[0.304]}\end{array}$ \\
\hline France & $\begin{array}{l}-0.014 \\
(0.014) \\
{[0.017]}\end{array}$ & $\begin{array}{l}-0.050 \\
(0.027) \\
{[0.032]}\end{array}$ & $\begin{array}{c}0.036 \\
(0.023) \\
{[0.027]}\end{array}$ & $\begin{array}{l}-0.004 \\
(0.022) \\
{[0.029]}\end{array}$ & $\begin{array}{l}-0.054 \\
(0.036) \\
{[0.034]}\end{array}$ & $\begin{array}{c}0.050 \\
(0.029) \\
{[0.018]}\end{array}$ \\
\hline Italy & $\begin{array}{l}-0.026 \\
(0.015) \\
{[0.013]}\end{array}$ & $\begin{array}{l}-0.064 \\
(0.025) \\
{[0.029]}\end{array}$ & $\begin{array}{c}0.038 \\
(0.020) \\
{[0.025]}\end{array}$ & $\begin{array}{l}-0.047 \\
(0.027) \\
{[0.025]}\end{array}$ & $\begin{array}{c}-0.148 \\
(0.061) \\
{[0.060]}\end{array}$ & $\begin{array}{c}0.102 \\
(0.055) \\
{[0.054]}\end{array}$ \\
\hline Spain & $\begin{array}{l}-0.033 \\
(0.009) \\
{[0.015]}\end{array}$ & $\begin{array}{l}-0.139 \\
(0.039) \\
{[0.070]}\end{array}$ & $\begin{array}{c}0.106 \\
(0.038) \\
{[0.068]}\end{array}$ & $\begin{array}{c}0.004 \\
(0.008) \\
{[0.007]}\end{array}$ & $\begin{array}{c}-0.052 \\
(0.039) \\
{[0.041]}\end{array}$ & $\begin{array}{c}0.056 \\
(0.039) \\
{[0.040]}\end{array}$ \\
\hline Netherlands & $\begin{array}{l}-0.102 \\
(0.034) \\
{[0.027]}\end{array}$ & $\begin{array}{l}-0.137 \\
(0.048) \\
{[0.040]}\end{array}$ & $\begin{array}{c}0.035 \\
(0.033) \\
{[0.029]}\end{array}$ & $\begin{array}{l}-0.093 \\
(0.039) \\
{[0.039]}\end{array}$ & $\begin{array}{c}-0.122 \\
(0.060) \\
{[0.049]}\end{array}$ & $\begin{array}{c}0.029 \\
(0.045) \\
{[0.030]}\end{array}$ \\
\hline Switzerland & $\begin{array}{l}-0.040 \\
(0.035) \\
{[0.048]}\end{array}$ & $\begin{array}{l}-0.129 \\
(0.061) \\
{[0.077]}\end{array}$ & $\begin{array}{c}0.089 \\
(0.050) \\
{[0.061]}\end{array}$ & $\begin{array}{l}-0.028 \\
(0.033) \\
{[0.031]}\end{array}$ & $\begin{array}{l}-0.091 \\
(0.060) \\
{[0.055]}\end{array}$ & $\begin{array}{c}0.062 \\
(0.050) \\
{[0.046]}\end{array}$ \\
\hline Sweden & $\begin{array}{l}-0.055 \\
(0.034) \\
{[0.033]}\end{array}$ & $\begin{array}{l}-0.061 \\
(0.047) \\
{[0.042]}\end{array}$ & $\begin{array}{c}0.006 \\
(0.033) \\
{[0.026]}\end{array}$ & $\begin{array}{l}-0.085 \\
(0.060) \\
{[0.054]}\end{array}$ & $\begin{array}{l}-0.112 \\
(0.076) \\
{[0.071]}\end{array}$ & $\begin{array}{c}0.027 \\
(0.046) \\
{[0.047]}\end{array}$ \\
\hline Belgium & $\begin{array}{l}-0.031 \\
(0.063) \\
{[0.040]}\end{array}$ & $\begin{array}{l}-0.025 \\
(0.131) \\
{[0.079]}\end{array}$ & $\begin{array}{l}-0.006 \\
(0.114) \\
{[0.069]}\end{array}$ & $\begin{array}{l}-0.118 \\
(0.058) \\
{[0.059]}\end{array}$ & $\begin{array}{c}-0.174 \\
(0.136) \\
{[0.141]}\end{array}$ & $\begin{array}{c}0.056 \\
(0.123) \\
{[0.128]}\end{array}$ \\
\hline Austria & $\begin{array}{l}-0.024 \\
(0.076) \\
{[0.048]}\end{array}$ & $\begin{array}{l}-0.033 \\
(0.083) \\
{[0.054]}\end{array}$ & $\begin{array}{c}0.010 \\
(0.033) \\
{[0.024]}\end{array}$ & $\begin{array}{l}-0.030 \\
(0.075) \\
{[0.083]}\end{array}$ & $\begin{array}{c}-0.079 \\
(0.120) \\
{[0.115]}\end{array}$ & $\begin{array}{c}0.048 \\
(0.094) \\
{[0.080]}\end{array}$ \\
\hline Norway & $\begin{array}{l}-0.098 \\
(0.058) \\
{[0.035]}\end{array}$ & $\begin{array}{c}-0.074 \\
(0.140) \\
{[0.100]}\end{array}$ & $\begin{array}{l}-0.024 \\
(0.127) \\
{[0.093]}\end{array}$ & $\begin{array}{l}-0.148 \\
(0.048) \\
{[0.045]}\end{array}$ & $\begin{array}{c}-0.138 \\
(0.195) \\
{[0.166]}\end{array}$ & $\begin{array}{l}-0.010 \\
(0.188) \\
{[0.160]}\end{array}$ \\
\hline Portugal & $\begin{array}{l}-0.028 \\
(0.031) \\
{[0.023]}\end{array}$ & $\begin{array}{l}-0.059 \\
(0.053) \\
{[0.035]}\end{array}$ & $\begin{array}{c}0.032 \\
(0.043) \\
{[0.026]}\end{array}$ & $\begin{array}{l}-0.053 \\
(0.040) \\
{[0.040]}\end{array}$ & $\begin{array}{l}-0.089 \\
(0.074) \\
{[0.051]}\end{array}$ & $\begin{array}{c}0.035 \\
(0.063) \\
{[0.032]}\end{array}$ \\
\hline
\end{tabular}

Notes: Table gives OLS and IV estimates, where estimation begins in 1979. See Table 1 for details. Results for pooled models are reported in the text. 
Figure 1. IV and IV-OLS and Country Characteristics

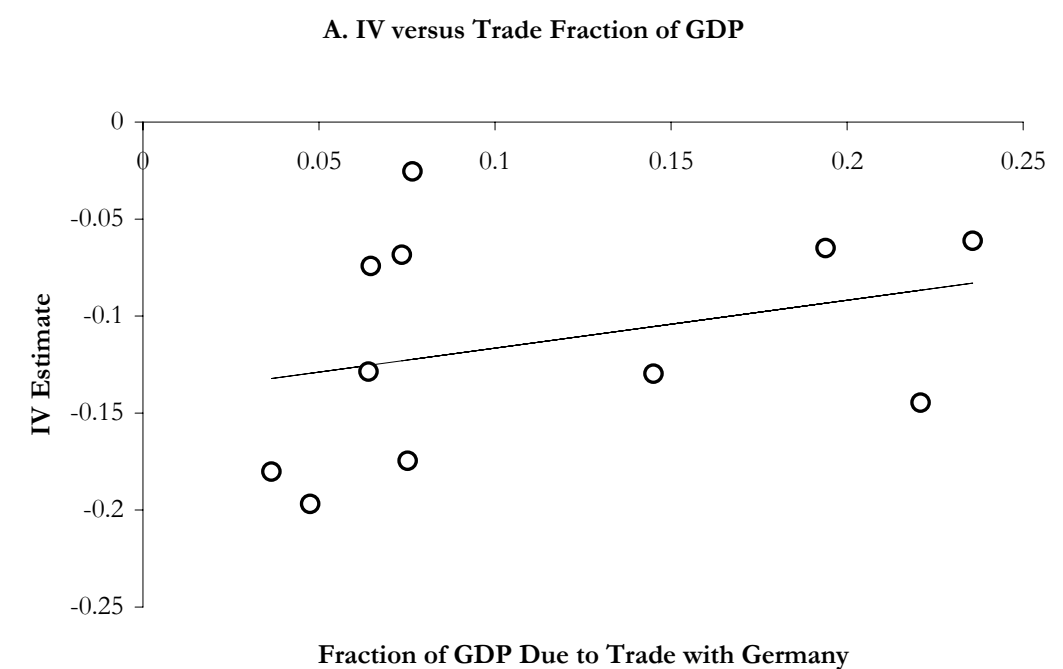

C. OLS-IV Difference versus Trade Fraction of GDP

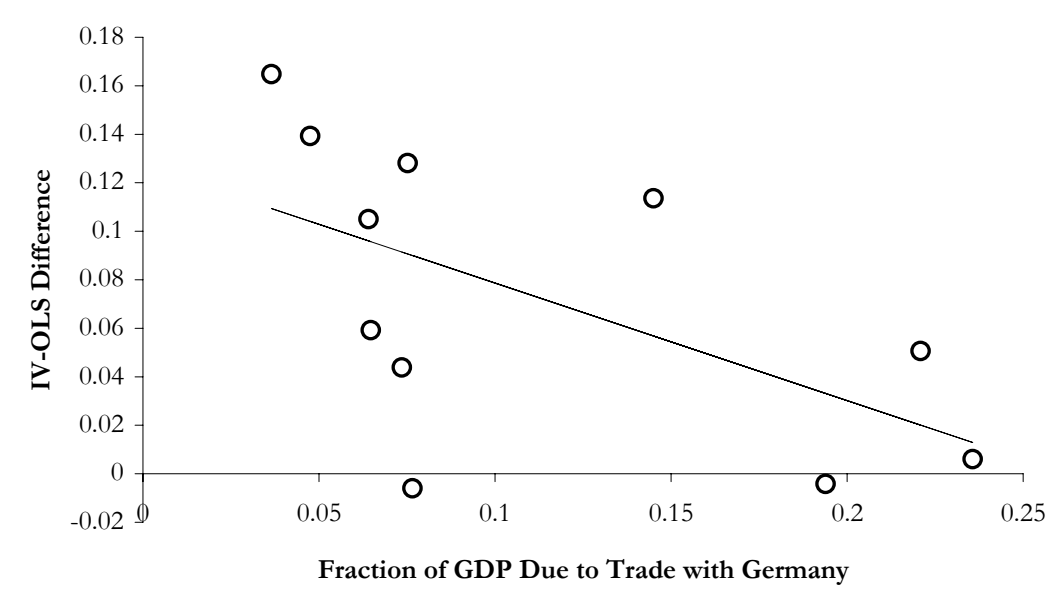

B. IV versus Exchange Rate Volatility

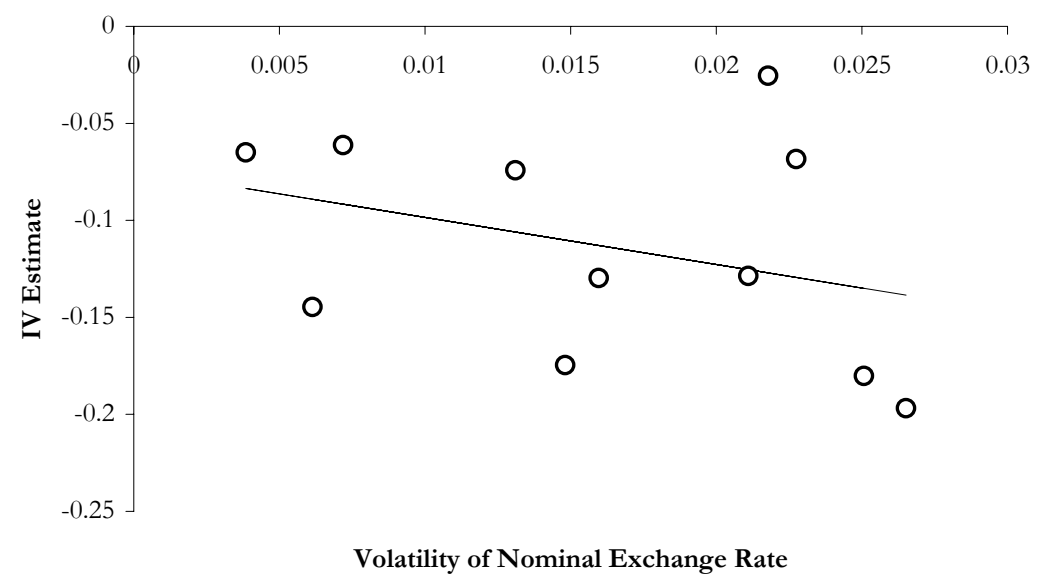

D. OLS-IV Difference versus Exchange Rate Volatility

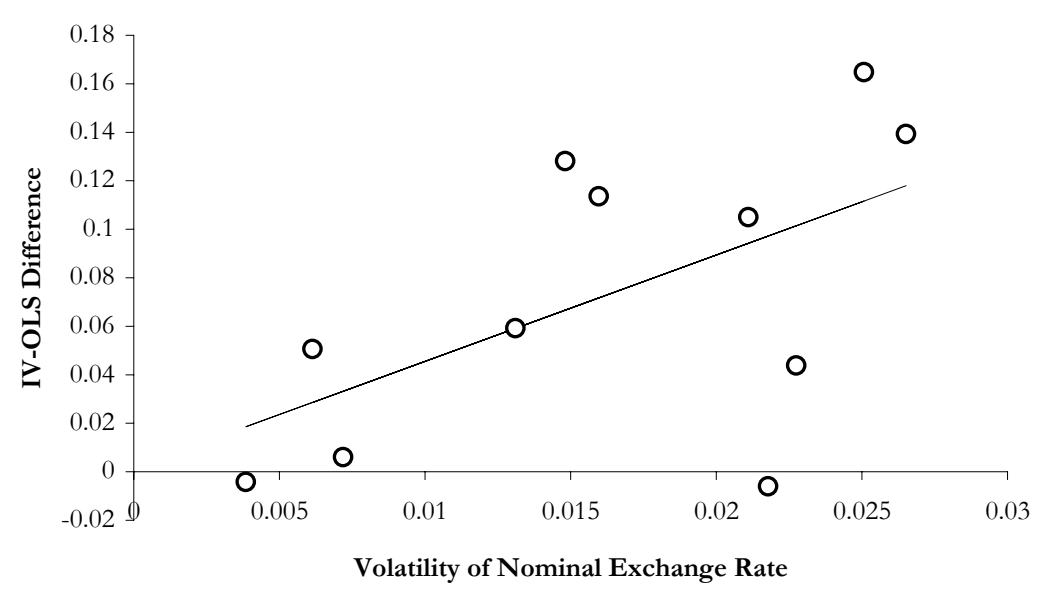


Table A.1. Country Summary Statistics

\begin{tabular}{|c|c|c|c|c|c|c|}
\hline & & & & & & \\
\hline Country & GDP & Trade/GDP & sd(NER) & GDP Growth & Interest Rate & Inflation \\
\hline Austria & 251.46 & 0.194 & 0.004 & 0.005 & 0.065 & 0.038 \\
\hline & - & - & - & $(0.081)$ & $(0.023)$ & $(0.018)$ \\
\hline Belgium & 302.22 & 0.236 & 0.007 & 0.005 & 0.070 & 0.029 \\
\hline & - & - & - & $(0.081)$ & $(0.023)$ & $(0.018)$ \\
\hline France & 1747.97 & 0.065 & 0.013 & 0.005 & 0.096 & 0.059 \\
\hline & - & - & - & $(0.007)$ & $(0.043)$ & $(0.040)$ \\
\hline Germany & 2400.66 & - & - & 0.005 & 0.060 & 0.032 \\
\hline & - & - & - & $(0.010)$ & $(0.023)$ & $(0.015)$ \\
\hline Great Britain & 1794.86 & 0.047 & 0.027 & 0.005 & 0.090 & 0.076 \\
\hline & - & - & - & $(0.010)$ & $(0.037)$ & $(0.055)$ \\
\hline Italy & 1465.90 & 0.064 & 0.021 & 0.005 & 0.124 & 0.096 \\
\hline & - & - & - & $(0.008)$ & $(0.042)$ & $(0.054)$ \\
\hline Netherlands & 511.56 & 0.221 & 0.006 & 0.006 & 0.066 & 0.021 \\
\hline & - & - & - & $(0.009)$ & $(0.025)$ & $(0.016)$ \\
\hline Norway & 221.58 & 0.075 & 0.015 & 0.010 & 0.101 & 0.050 \\
\hline & - & - & - & $(0.041)$ & $(0.040)$ & $(0.038)$ \\
\hline Portugal & 149.45 & 0.074 & 0.023 & 0.007 & 0.147 & 0.130 \\
\hline & - & - & - & $(0.019)$ & $(0.053)$ & $(0.078)$ \\
\hline Spain & 836.10 & 0.037 & 0.025 & 0.006 & 0.126 & 0.095 \\
\hline & - & - & - & $(0.005)$ & $(0.048)$ & $(0.054)$ \\
\hline Sweden & 300.80 & 0.077 & 0.022 & 0.007 & 0.103 & 0.046 \\
\hline & - & - & - & $(0.116)$ & $(0.038)$ & $(0.038)$ \\
\hline Switzerland & 309.47 & 0.145 & 0.016 & 0.003 & 0.027 & 0.030 \\
\hline & - & - & - & $(0.012)$ & $(0.025)$ & $(0.022)$ \\
\hline
\end{tabular}

Notes: All other variables are averaged over 1974-1998. Standard deviations are in parentheses. Trade is the total value of bilateral trade between the country and Germany. The exchange rate volatility measure, sd(NER), is calculated by taking the standard deviation of the change of end-of-month $\log$ nominal exchange rate viz. Germany over 1974Q1-1998Q4. Output growth is the quartlery rate. It is calculated by first deseasonalizing deseasonalizing output growth for each country. The interest rate is a quarterly average of the domestic call/money market rate. The inflation rate is calculated from the annual average of the quarterly GDP price deflator. 
Table A.2. Entry and Realignment Dates into EMS

\begin{tabular}{|c|c|c|c|c|c|c|c|c|c|c|}
\hline Date & Germany & Belgium & Denmark & France & Ireland & Netherlands & Italy & Spain & Great Britain & Portugal \\
\hline 1979Q3 & +2.00 & & -2.86 & & & & & $\mathrm{NM}$ & NM & $\mathrm{NM}$ \\
\hline 1979Q4 & & & -4.76 & & & & & NM & NM & $\mathrm{NM}$ \\
\hline 1981Q1 & & & & & & & -6.00 & NM & NM & NM \\
\hline 1981Q4 & +5.50 & & & -3.00 & & +5.50 & -3.00 & NM & NM & $\mathrm{NM}$ \\
\hline 1982Q1 & & -8.50 & -3.00 & & & & & NM & NM & NM \\
\hline 1982Q2 & +4.25 & & & -5.75 & & +4.25 & -2.75 & NM & NM & $\mathrm{NM}$ \\
\hline 1983Q1 & +5.50 & +1.50 & +2.50 & -2.50 & -3.50 & +3.50 & -2.50 & $\mathrm{NM}$ & NM & $\mathrm{NM}$ \\
\hline 1985Q3 & +2.00 & +2.00 & +2.00 & 2.00 & 2.00 & +2.00 & -6.00 & NM & NM & NM \\
\hline 1986Q2 & +3.00 & +1.00 & +1.00 & -3.00 & & +3.00 & & $\mathrm{NM}$ & NM & $\mathrm{NM}$ \\
\hline 1986Q3 & & & & & -8.00 & & & $\mathrm{NM}$ & NM & NM \\
\hline 1987Q1 & +3.00 & +2.00 & & & & +3.00 & & $\mathrm{NM}$ & NM & $\mathrm{NM}$ \\
\hline 1990Q1 & & & & & & & -3.86 & & NM & NM \\
\hline 1992Q3 & +3.50 & +3.50 & +3.50 & +3.50 & +3.50 & +3.50 & -3.50 & +3.50 & +3.50 & +3.50 \\
\hline 1992Q3 & & & & & & & & -5.00 & $\mathrm{NM}$ & \\
\hline 1993Q1 & & & & & -10.00 & & & & $\mathrm{NM}$ & \\
\hline 1993Q2 & & & & & & & & -8.00 & $\mathrm{NM}$ & -6.50 \\
\hline 1995Q1 & & & & & & & & -7.00 & & -3.50 \\
\hline Entry Date & 1979Q1 & 1979Q1 & 1979Q1 & 1979Q1 & 1979Q1 & 1979Q1 & 1979Q1 & 1989Q1 & 1990Q1 & 1992Q1 \\
\hline Band & \pm 2.25 & \pm 2.25 & \pm 2.25 & \pm 2.25 & \pm 2.25 & \pm 2.25 & \pm 6.00 & \pm 6.00 & \pm 6.00 & \pm 6.00 \\
\hline
\end{tabular}

Note: All realignment values are percentage changes of the currency's bilateral central rate against those currencies who bilateral parities were not realigned. The entry exchange rate band is in percentages. "NM" stands for non-member. Source: Bofinger (2000). 
Table A.3. Unit Root and Cointegration Tests For Quarterly Interest Rates

No Controls

\begin{tabular}{|c|c|c|c|c|}
\hline \multirow[b]{2}{*}{ Country } & \multicolumn{2}{|c|}{ Dickey-Fuller } & \multicolumn{2}{|c|}{$\begin{array}{c}\text { 4th Order Augmented } \\
\text { Dickey-Fuller }\end{array}$} \\
\hline & $\begin{array}{c}\text { Interest } \\
\text { Rates }\end{array}$ & Residuals & $\begin{array}{c}\text { Interest } \\
\text { Rates }\end{array}$ & Residuals \\
\hline Germany & $\begin{array}{c}0.911 \\
(0.043) \\
{[2.079]}\end{array}$ & & $\begin{array}{c}0.865 \\
(0.045) \\
{[2.990]}\end{array}$ & \\
\hline Great Britain & $\begin{array}{c}0.917 \\
(0.036) \\
{[2.301]}\end{array}$ & $\begin{array}{c}0.866 \\
(0.043) \\
{[3.153]}\end{array}$ & $\begin{array}{c}0.917 \\
(0.040) \\
{[2.067]}\end{array}$ & $\begin{array}{c}0.869 \\
(0.053) \\
{[2.468]}\end{array}$ \\
\hline France & $\begin{array}{c}0.815 \\
(0.061) \\
{[3.037]}\end{array}$ & $\begin{array}{c}0.623 \\
(0.081) \\
{[4.644]}\end{array}$ & $\begin{array}{c}0.879 \\
(0.073) \\
{[1.670]}\end{array}$ & $\begin{array}{c}0.839 \\
(0.098) \\
{[1.644]}\end{array}$ \\
\hline Italy & $\begin{array}{c}0.797 \\
(0.065) \\
{[3.122]}\end{array}$ & $\begin{array}{c}0.715 \\
(0.073) \\
{[3.928]}\end{array}$ & $\begin{array}{c}0.904 \\
(0.077) \\
{[1.250]}\end{array}$ & $\begin{array}{c}0.884 \\
(0.086) \\
{[1.363]}\end{array}$ \\
\hline Spain & $\begin{array}{c}0.686 \\
(0.078) \\
{[4.034]}\end{array}$ & $\begin{array}{c}0.650 \\
(0.080) \\
{[4.350]}\end{array}$ & $\begin{array}{c}0.797 \\
(0.105) \\
{[1.944]}\end{array}$ & $\begin{array}{c}0.771 \\
(0.109) \\
{[2.105]}\end{array}$ \\
\hline Netherlands & $\begin{array}{c}0.933 \\
(0.044) \\
{[1.537]}\end{array}$ & $\begin{array}{c}0.710 \\
(0.081) \\
{[3.573]}\end{array}$ & $\begin{array}{c}0.797 \\
(0.105) \\
{[1.944]}\end{array}$ & $\begin{array}{c}0.771 \\
(0.109) \\
{[2.105]}\end{array}$ \\
\hline Switzerland & $\begin{array}{c}0.956 \\
(0.030) \\
{[1.473]}\end{array}$ & $\begin{array}{c}0.931 \\
(0.038) \\
{[1.842]}\end{array}$ & $\begin{array}{c}0.947 \\
(0.032) \\
{[1.694]}\end{array}$ & $\begin{array}{c}0.948 \\
(0.040) \\
{[1.311]}\end{array}$ \\
\hline Sweden & $\begin{array}{c}0.721 \\
(0.087) \\
{[3.206]}\end{array}$ & $\begin{array}{c}0.530 \\
(0.106) \\
{[4.413]}\end{array}$ & $\begin{array}{c}0.831 \\
(0.116) \\
{[1.458]}\end{array}$ & $\begin{array}{c}0.707 \\
(0.151) \\
{[1.938]}\end{array}$ \\
\hline Belgium & $\begin{array}{c}0.922 \\
(0.042) \\
{[1.865]}\end{array}$ & $\begin{array}{c}0.715 \\
(0.087) \\
{[3.277]}\end{array}$ & $\begin{array}{c}0.900 \\
(0.046) \\
{[2.180]}\end{array}$ & $\begin{array}{c}0.833 \\
(0.100) \\
{[1.665]}\end{array}$ \\
\hline Austria & $\begin{array}{c}0.940 \\
(0.038) \\
{[1.570]}\end{array}$ & $\begin{array}{c}0.640 \\
(0.079) \\
{[4.578]}\end{array}$ & $\begin{array}{c}0.876 \\
(0.043) \\
{[2.885]}\end{array}$ & $\begin{array}{c}0.717 \\
(0.099) \\
{[2.864]}\end{array}$ \\
\hline Norway & $\begin{array}{c}0.759 \\
(0.067) \\
{[3.597]}\end{array}$ & $\begin{array}{c}0.731 \\
(0.069) \\
{[3.875]}\end{array}$ & $\begin{array}{c}0.848 \\
(0.080) \\
{[1.904]}\end{array}$ & $\begin{array}{c}0.817 \\
(0.084) \\
{[2.176]}\end{array}$ \\
\hline Portugal & $\begin{array}{c}0.961 \\
(0.042) \\
{[0.935]}\end{array}$ & $\begin{array}{c}0.901 \\
(0.052) \\
{[1.887]}\end{array}$ & $\begin{array}{c}0.848 \\
(0.080) \\
{[1.904]}\end{array}$ & $\begin{array}{c}0.817 \\
(0.084) \\
{[2.176]}\end{array}$ \\
\hline
\end{tabular}

One Lag of Growth, One Lag of Inflation

Four Lags of Growth, Four Lags of Inflation

\begin{tabular}{|c|c|c|c|c|c|c|c|}
\hline \multicolumn{2}{|c|}{ Dickey-Fuller } & \multicolumn{2}{|c|}{$\begin{array}{c}\text { 4th Order Augmented } \\
\text { Dickey-Fuller }\end{array}$} & \multicolumn{2}{|c|}{ Dickey-Fuller } & \multicolumn{2}{|c|}{$\begin{array}{c}\text { 4th Order Augmented } \\
\text { Dickey-Fuller }\end{array}$} \\
\hline $\begin{array}{c}\text { Interest } \\
\text { Rates }\end{array}$ & Residuals & $\begin{array}{c}\text { Interest } \\
\text { Rates }\end{array}$ & Residuals & $\begin{array}{c}\text { Interest } \\
\text { Rates }\end{array}$ & Residuals & $\begin{array}{c}\text { Interest } \\
\text { Rates }\end{array}$ & Residuals \\
\hline $\begin{array}{c}0.917 \\
(0.049) \\
{[1.700]}\end{array}$ & & $\begin{array}{c}0.854 \\
(0.049) \\
{[2.948]}\end{array}$ & & $\begin{array}{c}0.937 \\
(0.051) \\
{[1.248]}\end{array}$ & & $\begin{array}{c}0.884 \\
(0.058) \\
{[1.985]}\end{array}$ & \\
\hline $\begin{array}{c}0.929 \\
(0.037) \\
{[1.931]}\end{array}$ & $\begin{array}{c}0.868 \\
(0.043) \\
{[3.083]}\end{array}$ & $\begin{array}{c}0.955 \\
(0.041) \\
{[1.110]}\end{array}$ & $\begin{array}{c}0.885 \\
(0.053) \\
{[2.189]}\end{array}$ & $\begin{array}{c}0.944 \\
(0.037) \\
{[1.514]}\end{array}$ & $\begin{array}{c}0.794 \\
(0.056) \\
{[3.703]}\end{array}$ & $\begin{array}{c}0.952 \\
(0.045) \\
{[1.075]}\end{array}$ & $\begin{array}{c}0.851 \\
(0.063) \\
{[2.362]}\end{array}$ \\
\hline $\begin{array}{c}0.736 \\
(0.075) \\
{[3.527]}\end{array}$ & $\begin{array}{c}0.345 \\
(0.100) \\
{[6.520]}\end{array}$ & $\begin{array}{c}0.798 \\
(0.094) \\
{[2.151]}\end{array}$ & $\begin{array}{c}0.460 \\
(0.173) \\
{[3.131]}\end{array}$ & $\begin{array}{c}0.712 \\
(0.078) \\
{[3.709]}\end{array}$ & $\begin{array}{c}0.366 \\
(0.103) \\
{[6.149]}\end{array}$ & $\begin{array}{c}0.715 \\
(0.107) \\
{[2.681]}\end{array}$ & $\begin{array}{c}0.359 \\
(0.176) \\
{[3.644]}\end{array}$ \\
\hline $\begin{array}{c}0.583 \\
(0.079) \\
{[5.316]}\end{array}$ & $\begin{array}{c}0.382 \\
(0.095) \\
{[6.503]}\end{array}$ & $\begin{array}{c}0.657 \\
(0.104) \\
{[3.295]}\end{array}$ & $\begin{array}{c}0.355 \\
(0.172) \\
{[3.750]}\end{array}$ & $\begin{array}{c}0.515 \\
(0.090) \\
{[5.394]}\end{array}$ & $\begin{array}{c}0.379 \\
(0.094) \\
{[6.581]}\end{array}$ & $\begin{array}{c}0.638 \\
(0.138) \\
{[2.628]}\end{array}$ & $\begin{array}{c}0.307 \\
(0.177) \\
{[3.914]}\end{array}$ \\
\hline $\begin{array}{c}0.651 \\
(0.080) \\
{[4.380]}\end{array}$ & $\begin{array}{c}0.600 \\
(0.091) \\
{[4.373]}\end{array}$ & $\begin{array}{c}0.725 \\
(0.112) \\
{[2.457]}\end{array}$ & $\begin{array}{c}0.730 \\
(0.150) \\
{[1.810]}\end{array}$ & $\begin{array}{c}0.597 \\
(0.089) \\
{[4.543]}\end{array}$ & $\begin{array}{c}0.524 \\
(0.094) \\
{[5.055]}\end{array}$ & $\begin{array}{c}0.612 \\
(0.145) \\
{[2.675]}\end{array}$ & $\begin{array}{c}0.320 \\
(0.169) \\
{[4.024]}\end{array}$ \\
\hline $\begin{array}{c}0.915 \\
(0.048) \\
{[1.796]}\end{array}$ & $\begin{array}{c}0.674 \\
(0.087) \\
{[3.756]}\end{array}$ & $\begin{array}{c}0.938 \\
(0.044) \\
{[1.435]}\end{array}$ & $\begin{array}{c}0.737 \\
(0.099) \\
{[2.644]}\end{array}$ & $\begin{array}{c}0.936 \\
(0.053) \\
{[1.206]}\end{array}$ & $\begin{array}{c}0.733 \\
(0.084) \\
{[3.196]}\end{array}$ & $\begin{array}{c}1.020 \\
(0.060) \\
{[0.333]}\end{array}$ & $\begin{array}{c}0.727 \\
(0.096) \\
{[2.856]}\end{array}$ \\
\hline $\begin{array}{c}0.966 \\
(0.029) \\
{[1.154]}\end{array}$ & $\begin{array}{c}0.922 \\
(0.041) \\
{[1.919]}\end{array}$ & $\begin{array}{c}0.958 \\
(0.032) \\
{[1.336]}\end{array}$ & $\begin{array}{c}0.947 \\
(0.042) \\
{[1.277]}\end{array}$ & $\begin{array}{c}0.955 \\
(0.029) \\
{[1.546]}\end{array}$ & $\begin{array}{c}0.916 \\
(0.043) \\
{[1.960]}\end{array}$ & $\begin{array}{c}0.960 \\
(0.031) \\
{[1.311]}\end{array}$ & $\begin{array}{c}0.946 \\
(0.046) \\
{[1.182]}\end{array}$ \\
\hline $\begin{array}{c}0.722 \\
(0.089) \\
{[3.132]}\end{array}$ & $\begin{array}{c}0.503 \\
(0.115) \\
{[4.325]}\end{array}$ & $\begin{array}{c}0.835 \\
(0.117) \\
{[1.413]}\end{array}$ & $\begin{array}{c}0.681 \\
(0.167) \\
{[1.911]}\end{array}$ & $\begin{array}{c}0.676 \\
(0.101) \\
{[3.194]}\end{array}$ & $\begin{array}{c}0.476 \\
(0.120) \\
{[4.351]}\end{array}$ & $\begin{array}{c}0.781 \\
(0.119) \\
{[1.843]}\end{array}$ & $\begin{array}{c}0.578 \\
(0.197) \\
{[2.144]}\end{array}$ \\
\hline $\begin{array}{c}0.865 \\
(0.054) \\
{[2.516]}\end{array}$ & $\begin{array}{c}0.346 \\
(0.127) \\
{[5.145]}\end{array}$ & $\begin{array}{c}0.859 \\
(0.058) \\
{[2.454]}\end{array}$ & $\begin{array}{c}0.619 \\
(0.201) \\
{[1.899]}\end{array}$ & $\begin{array}{c}0.893 \\
(0.069) \\
{[1.546]}\end{array}$ & $\begin{array}{c}0.469 \\
(0.119) \\
{[4.480]}\end{array}$ & $\begin{array}{c}0.908 \\
(0.080) \\
{[1.148]}\end{array}$ & $\begin{array}{c}0.328 \\
(0.214) \\
{[3.138]}\end{array}$ \\
\hline $\begin{array}{c}0.938 \\
(0.040) \\
{[1.553]}\end{array}$ & $\begin{array}{c}0.637 \\
(0.081) \\
{[4.486]}\end{array}$ & $\begin{array}{c}0.871 \\
(0.044) \\
{[2.933]}\end{array}$ & $\begin{array}{c}0.703 \\
(0.107) \\
{[2.769]}\end{array}$ & $\begin{array}{c}0.959 \\
(0.039) \\
{[1.061]}\end{array}$ & $\begin{array}{c}0.646 \\
(0.082) \\
{[4.343]}\end{array}$ & $\begin{array}{c}0.898 \\
(0.046) \\
{[2.196]}\end{array}$ & $\begin{array}{c}0.570 \\
(0.114) \\
{[3.762]}\end{array}$ \\
\hline $\begin{array}{c}0.751 \\
(0.067) \\
{[3.703]}\end{array}$ & $\begin{array}{c}0.738 \\
(0.070) \\
{[3.764]}\end{array}$ & $\begin{array}{c}0.844 \\
(0.081) \\
{[1.926]}\end{array}$ & $\begin{array}{c}0.820 \\
(0.085) \\
{[2.126]}\end{array}$ & $\begin{array}{c}0.769 \\
(0.070) \\
{[3.322]}\end{array}$ & $\begin{array}{c}0.743 \\
(0.073) \\
{[3.533]}\end{array}$ & $\begin{array}{c}0.843 \\
(0.083) \\
{[1.887]}\end{array}$ & $\begin{array}{c}0.833 \\
(0.089) \\
{[1.880]}\end{array}$ \\
\hline $\begin{array}{c}0.938 \\
(0.048) \\
{[1.279]}\end{array}$ & $\begin{array}{c}0.749 \\
(0.102) \\
{[2.468]}\end{array}$ & $\begin{array}{c}1.015 \\
(0.056) \\
{[0.275]}\end{array}$ & $\begin{array}{c}1.145 \\
(0.131) \\
{[1.102]}\end{array}$ & $\begin{array}{c}0.890 \\
(0.063) \\
{[1.755]}\end{array}$ & $\begin{array}{c}0.727 \\
(0.093) \\
{[2.929]}\end{array}$ & $\begin{array}{c}0.956 \\
(0.081) \\
{[0.538]}\end{array}$ & $\begin{array}{c}0.545 \\
(0.163) \\
{[2.787]}\end{array}$ \\
\hline
\end{tabular}

Notes: The columns labeled "Interest Rates" shows autocorroelation coefficients for countries' quarterly call money rate. The columns labeled "Residuals" show autocorrelation

coefficients for the fitted residuals of a regression of national on German interest rates. Heteroscedasticity-robust standard errors are in parentheses. T-ratios for the null-hypothesis

of a unit coefficient are in squared brackets. The 5\% critical value for rejection of null of unit root is 3.17 for columns labeled "Interest rates" and 3.27 for columns labeled "Residuals". 

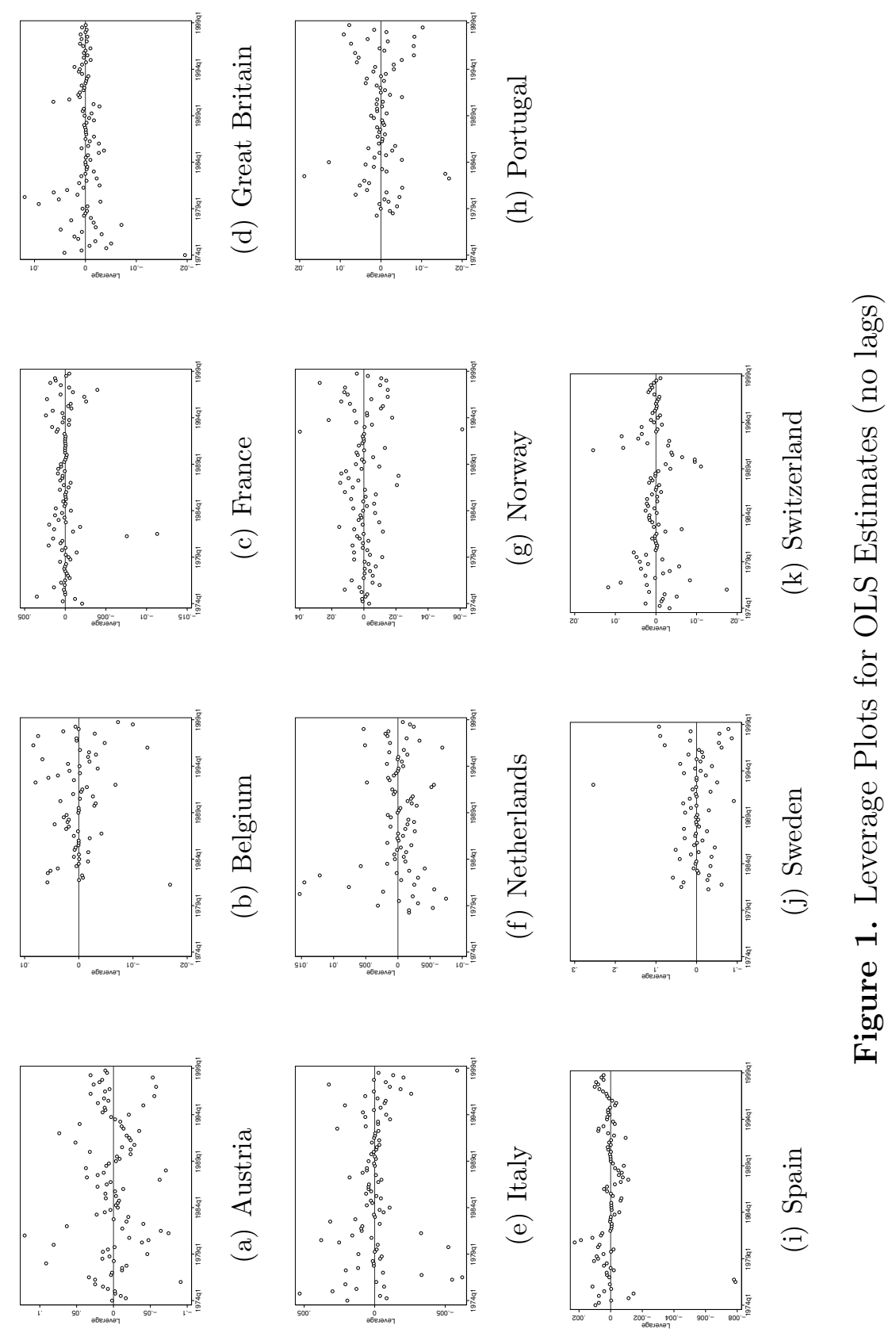

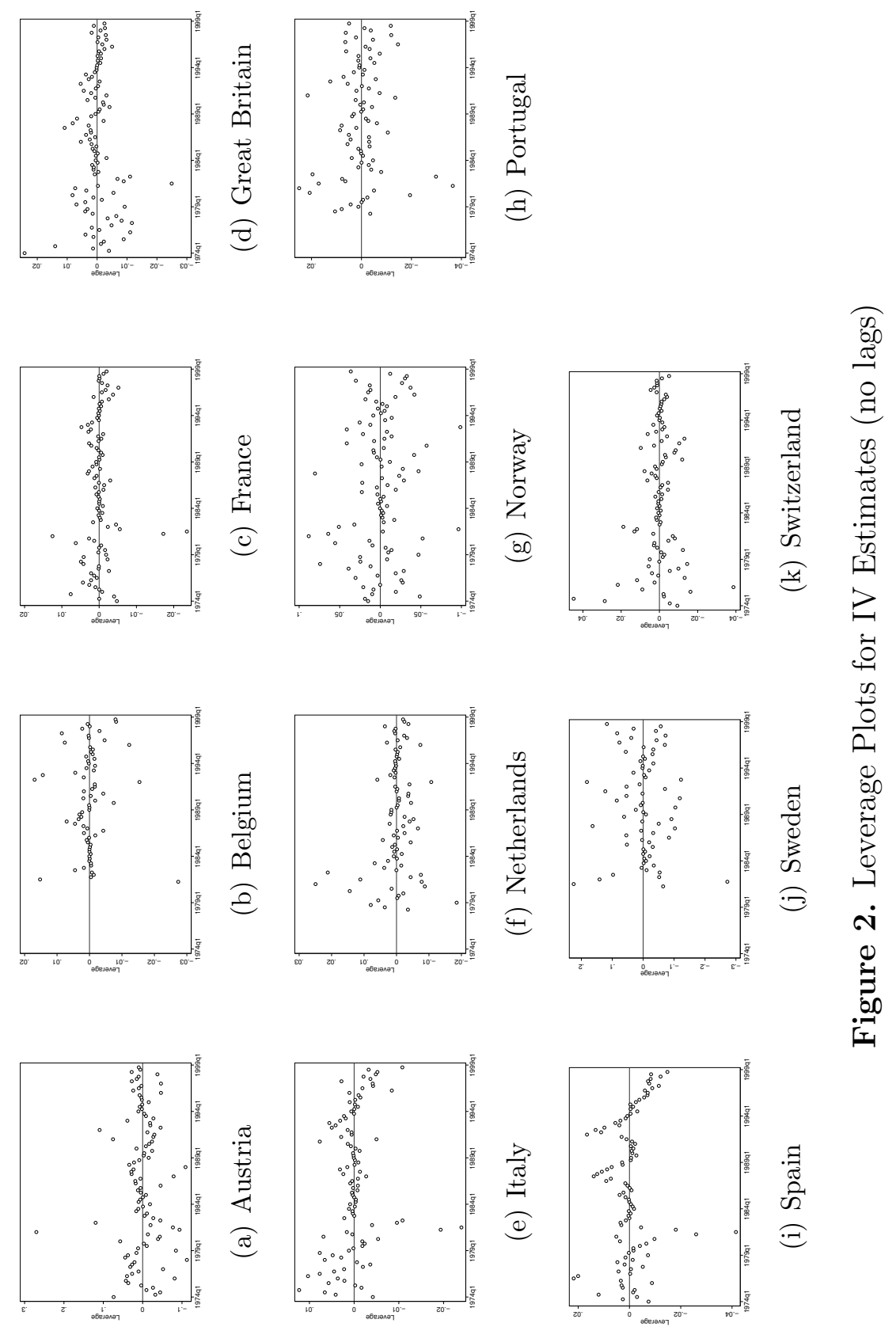